\title{
Working
}

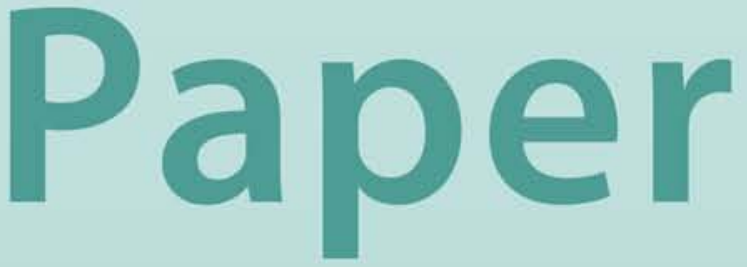




\section{Ten Years After the CFA Franc Devaluation: Progress Toward Regional Integration in the WAEMU}

Pierre van den Boogaerde and Charalambos Tsangarides 


\title{
IMF Working Paper
}

\section{African Department \\ Ten Years After the CFA Franc Devaluation: Progress Toward Regional Integration in the WAEMU}

Prepared by Pierre van den Boogaerde and Charalambos Tsangarides ${ }^{1}$

Authorized for distribution by Francesco Caramazza

July 2005

\begin{abstract}
This Working Paper should not be reported as representing the views of the IMF. The views expressed in this Working Paper are those of the author(s) and do not necessarily represent those of the IMF or IMF policy. Working Papers describe research in progress by the author(s) and are published to elicit comments and to further debate.

This paper takes stock of the achievements toward integration in the West African Economic and Monetary Union (WAEMU) 10 years after the 1994 devaluation of the CFA franc. It investigates the lessons learned and evaluates progress toward economic convergence, examines the evolution of trade and competitiveness, and points to ways to remove impediments to greater integration. The paper concludes that a continued political commitment will be needed to overcome the important dissimilarities between WAEMU member countries that have limited the degree of convergence achieved to date, and to advance toward a full-fledged economic union.

JEL Classification Numbers: E58, E61, F15, F33.
\end{abstract}

Keywords: WAEMU; CFA franc; regional integration

Author(s) E-Mail Address: pvandenboogaerde@imf.org; ctsangarides@imf.org

\footnotetext{
${ }^{1}$ The authors would like to thank Anne-Marie Gulde-Wolf, Robert Powell, Jon Shields, and Amadou Sy for helpful comments. Issouf Samake provided excellent research assistance on an earlier draft of this paper, and Bella Nestorova on the current version.
} 


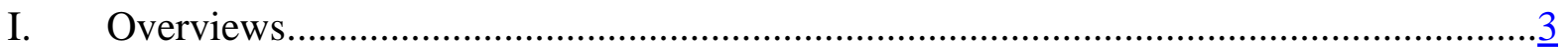

II. Rationale for Convergence and Achievements ................................................................

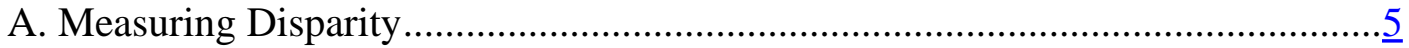

B. Real Sector Developments ...............................................................................

C. Fiscal Developments ...........................................................................

D. Monetary Aspects of the Integration Process ....................................................13

III. Intraregional Trade and Competitiveness ……….......................................................

A. Characteristics of Trade ...........................................................................14

B. Competitiveness ……………………...............................................................

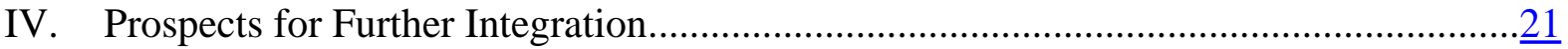

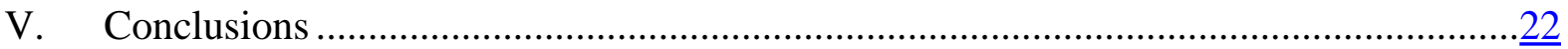

Appendices

1. Calculation of the Internal Real Exchange Rage ……..................................................23

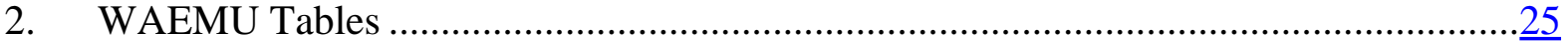

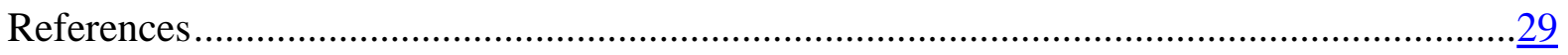

Boxes

1. WAEMU Member Countries..................................................................................

2. WAEMU: Migratory Flows .........................................................................................

Figures

1. WAEMU: Real GDP Growth, 1990-2003 ………................................................

2. WAEMU: Overall Fiscal Deficit, 1990-2003 ……...............................................

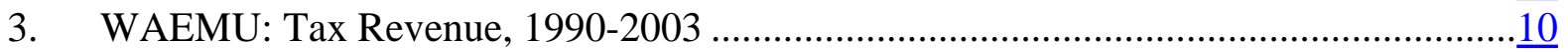

4. WAEMU: Total Expenditure, 1990-2003................................................................12

5. WAEMU: Investment Expenditure, 1990-2003 ……..................................................

6. WAEMU: Civil Service Wage Expenditures, 1990-2003 …………………………......13

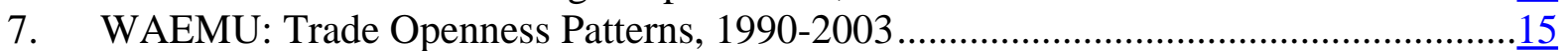

8. WAEMU: Evolution of Trade Openness, 1990-2003..............................................15

9. WAEMU: Ratio of Intrazone Exports to Total Exports, 1990-2003 …………..............16

10. WAEMU: Weight of Each Country in Intrazone Exports of Goods, 1990-2003.............16

11. WAEMU: Ratio of Intrazone Imports to Total Imports, 1990-2003 ……………….......16

12. WAEMU: Weight of Each Country in Intrazone Imports of Goods, 1990-2003.............17

13. WAEMU: Terms of Trade, Export Prices, and Exchange Rate ....................................19

14. WAMEU: Real Effective Exchange Rate..................................................................19

15. WAMEU: Ratio of Exports to Selected Groups' Total Imports....................................20

16. WAMEU: Profitability Indicators............................................................................. 


\section{OVERVIEWS}

On January 13, 1994, after the CFA franc was devalued by 50 percent in foreign currency terms, the governments of Benin, Burkina Faso, Côte d'Ivoire, Mali, Niger, Senegal, and Togo signed a treaty creating the West African Economic and Monetary Union (WAEMU). These seven countries had already been linked since 1960 through the West African Monetary Union (WAMU) ${ }^{2}$. They shared a common currency, the CFA franc, which was pegged to the French franc. Since 1999, the link has been to the euro. The government of Guinea Bissau joined the union as an eighth member in May 1997.

Following the 1994 devaluation, the seven WAMU countries felt the need to reinforce the monetary union with a customs union and common economic market, based on the free movement of persons, goods, services, and capital. This would be consolidated by common industrial and sectoral policies, common external tariffs and trade policies, and a common framework of regulations pertaining to fiscal policy, public finance and business accounting, commercial law, and investment promotion. To maintain macroeconomic stability and the integrity of the currency peg, a system of multilateral surveillance of macroeconomic policy was established that would ensure a convergence of key aggregates in the fiscal area.

Against this background, this paper examines whether the new economic union has led to stronger economic convergence between WAEMU member countries, based on an examination of data covering 1990-2003 and a "disparity indicator" to measure the degree or lack of convergence. ${ }^{3}$ It also points out how impediments to greater integration can be removed.

We divide the period under study into three subperiods characterized by different macroeconomic environments. In the first subperiod, 1990-93, the then WAMU economies were buffeted by adverse terms of trade movements, a significantly overvalued exchange rate, fiscal imbalances, insufficient efforts at internal adjustment, and a rapid accumulation of external debt. In the second subperiod, 1994-98, the devaluation of the common currency was accompanied by ambitious stabilization and structural adjustment programs. As a result, the newly competitive economies experienced strong economic expansion, a more balanced macroeconomic performance, and progress in transforming the structure of their economies. In the third subperiod, 1999-2003, the strong economic momentum brought about by the CFA franc devaluation gradually dissipated, with weaker output growth and improvements in fiscal and external deficits reversed in several countries. Also, the unfavorable economic

\footnotetext{
${ }^{2}$ Mali joined WAMU in 1984. At present, the WAEMU treaty coexists with the earlier WAMU treaty, but the two treaties will eventually be merged. For a more complete overview of the historical developments, see Masson and Pattillo (2004).

${ }^{3}$ Guinea-Bissau has been omitted from the study because it joined WAEMU only in May 1997.
} 
environment and the crisis in Côte d'Ivoire resulted in a softening in certain member governments' political commitment to the integration.

The rest of the paper is organized as follows. Section II examines the rationale for convergence and takes stock of achievements in this area in WAEMU. Section III analyzes the evolution of intraregional trade and competitiveness of member countries' economies. Section IV suggests ways to remove impediments to greater integration. Section V offers some concluding remarks.

\section{RATionAle For CONVERgENCE AND ACHIEVEMENTS}

The WAMU was established in 1960 to maintain the successful alignment of the currencies in the region to the French franc and to help integrate the member economies. ${ }^{4}$ Although the countries had a long tradition of sociopolitical cohesion and strong bonds in both culture and language, they did not exhibit the characteristics of an optimal currency area. ${ }^{5}$ In particular, WAMU countries lacked diversification, were subject to sizable asymmetric external shocks, and traded little with each other. The monetary union was based on the premise that by piggybacking on the monetary policy of a "disciplined” anchor currency the countries would benefit from nominal stability and low inflation, which would outweigh the loss of flexibility to respond to idiosyncratic shocks. Helped by favorable terms of trade developments, WAMU worked well in the two decades after the countries achieved their independence, but started to unravel in the mid-1980s because of a structural decline in commodity prices - which affected the economies differently-and the nominal appreciation of the French franc against the U.S. dollar. This caused the countries' competitive position to deteriorate and led, eventually, to the 1994 devaluation of the CFA franc.

There are significant differences between the member countries, including the size of their economies: Côte d'Ivoire accounts for about 40 percent of WAEMU's output, Senegal for about 20 percent, and the remaining six countries representing less than 10 percent each. Also, Côte d'Ivoire and Senegal, with their somewhat more developed industrial bases, ${ }^{6}$ and

\footnotetext{
${ }^{4}$ At the same time, five countries in Central Africa (Cameroon, Central African Republic, Chad, Congo, and Gabon) also formed a monetary union, the Communauté Economique et Monétaire d'Afrique Centrale (CEMAC).

${ }^{5}$ As noted in Bayoumi and Ostry (1995), "the main benefit from the existing common currency arrangements of the CFA franc zone may well come from the monetary stability generated by the peg with the French franc rather than the regional integration of members with each other" (p. 27).

${ }^{6}$ It is generally recognized that a more diversified production base implies greater net benefits to fixed exchange rates; see Kenen (1969).
} 
Benin and Togo with their transit trade, are far better off than the landlocked and agricultural countries of Burkina Faso, Mali, and Niger, resulting in significant migration from the Sahelian countries to the coastal states. Disparities in per capita incomes are large: in 2001, Côte d'Ivoire's income per capita in current U.S. dollars (US\$710) was more than four times higher than that of Guinea-Bissau (US\$160). Box 1 presents brief profiles for the WAEMU countries.

Against this background, the goal of an economic union is to enhance macroeconomic stability, improve economic performance and growth, and reduce poverty. In particular, promoting fiscal discipline, openness to international trade, and competition in the regional market would foster investment, ${ }^{7}$ enhance growth, and allow the poorer WAEMU country members to gradually gravitate toward the richer ones. ${ }^{8}$ Each member country could alleviate the drawback of its small economic size by using WAEMU to increase economic space and build complementary production structures. To promote differentiated production structures that could expand intraregional trade, a more ambitious and dynamic structural approach is needed to reduce transaction costs and to provide efficiency gains in areas such as transportation, energy, and telecommunications.

\section{A. Measuring Disparity}

To assess the degree of convergence (or lack thereof) of the member countries, we need to construct a quantitative measure. The literature describes various measures of convergence and the research on it, which was initiated by empirical work on growth. ${ }^{9}$ The measures include those of the dispersion of variables through time ( $\sigma$-convergence); measures of the relationship between initial and current values, or some sort of "mean reversion" ( $\beta$ convergence); some measure of rank concordance ( $\gamma$-convergence); and other measures of cointegrating relationships among variables.

\footnotetext{
${ }^{7}$ Rogoff and Reinhart (2003) show that while in the WAEMU the exchange arrangement has contributed to price stability, this was not enough to attract significant foreign direct investment (FDI).

${ }^{8}$ Wane (2004) finds that per capita income in lower-income WAEMU countries converges to per capita income in higher-income ones when economic policies are similar.

${ }^{9}$ The concept of convergence is an important feature of the neoclassical growth model: output levels of countries with similar technologies converge to a given level in the steady state. Three competing hypotheses have been the center of empirical work and much of the controversy surrounding convergence: the absolute convergence hypothesis, the conditional convergence hypothesis, and the club convergence hypothesis.
} 


\section{Box 1. WAEMU Member Countries}

\section{Larger, more diversified economies}

Côte d'Ivoire has the largest WAEMU economy with a population of 17.3 million and a GDP per capita of $\$ 710$. It is the largest cocoa producer in the world and among the largest exporters of coffee and palm oil. Since 1999, there has been political turmoil in the country.

Senegal has the second-largest WAEMU economy with a population of 11.1 million people and a GDP per capita of \$470. It exports fish, peanuts, phosphates, and cotton. Senegal is politically stable and has a long history of participating in international peacekeeping.

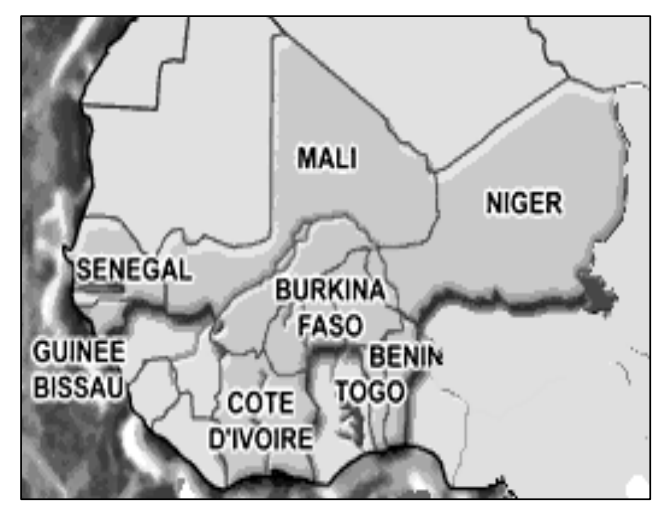

\section{Small, coastal countries}

Benin, with a population of 7.5 million has a GDP per capita of \$405. It is dependent on subsistence agriculture, cotton production, and regional trade. Its main export commodities are cotton, crude oil, palm products, and cocoa. The country is politically stable.

Guinea-Bissau, one of the 10 poorest countries in the world, joined WAEMU in 1997. Its GDP per capita is $\$ 160$, and its population is 1.5 million. The country now ranks sixth in world cashew production. It exports fish and seafood. Since 1974, Guinea-Bissau has experienced considerable political upheaval.

Togo's population of 5.7 million is heavily dependent on both commercial and subsistence agriculture. The country has been experiencing political unrest and as a result most bilateral and multilateral aid to Togo is frozen. It’s GDP per capita is $\$ 420$. It exports cotton, phosphates, coffee, and cocoa.

\section{Land-locked Sahelian countries}

Burkina Faso has a population of 13.9 million and a GDP per capita of \$285. One of the poorest countries in the world, landlocked Burkina Faso has few natural resources. It exports cotton, livestock, and gold.

Mali is among the poorest countries in the world, with 65 percent of its land area consisting of desert or semidesert. It has a population of 12.3 million and a GDP per capita of \$295. Mali exports cotton, gold, and livestock.

Niger, also one of the poorest countries in the world, has a population of 11.7 million and a GDP per capita of $\$ 188$. Its economy centers on subsistence crops, livestock, and some of the world's largest uranium deposits. 
For the purposes of our analysis, we construct a simple measure of convergence named "average disparity," which estimates a weighted variance of deviations for all the region's countries for every point in time. Let $X_{i t}$ be the observed value of a variable $X$ for country $i$ in year $t$. Next, define $P_{i t}$ as the weight of WAEMU member country $i$ in year $t$ for the observed variable $X$. Each country's nominal GDP share in the aggregated WAEMU nominal GDP was used to calculate the weights, so

$P_{i t}=\frac{G D P_{\text {it }}}{\sum_{\mathrm{i}=1}^{7} \mathrm{G} D P_{\mathrm{it}}}$. Finally, define $\bar{X}_{t}$ as the weighted average of the observation of variable $X$ in year $t$, calculated for each country as $\bar{X}_{t}=\sum_{i=1}^{7} P_{i t} X_{i t}{ }^{10}$

Using the above, the average disparity is calculated as the weighted standard deviation observed for each country vis-à-vis the WAEMU average for that year, namely, AverageDisparity $=\left\{\sum_{i=1}^{7} P_{i t}\left(X_{i t}-\bar{X}_{t}\right)^{2}\right\}^{1 / 2}$.

An estimated low (high) disparity through time indicates a tendency for convergence (divergence).

\section{B. Real Sector Developments}

The WAEMU countries stagnated in 1990-93 and experienced broadly uniform economic gains in the mid1990s; however, their economic performances differed from 1999 onwards. Although the adverse terms of trade combined with a significantly overvalued exchange rate affected all member countries in 1990-93, their growth performances were highly uneven (Appendix Table 1 and Figure 1). ${ }^{11}$ After the 1994 devaluation, all WAEMU economies experienced a

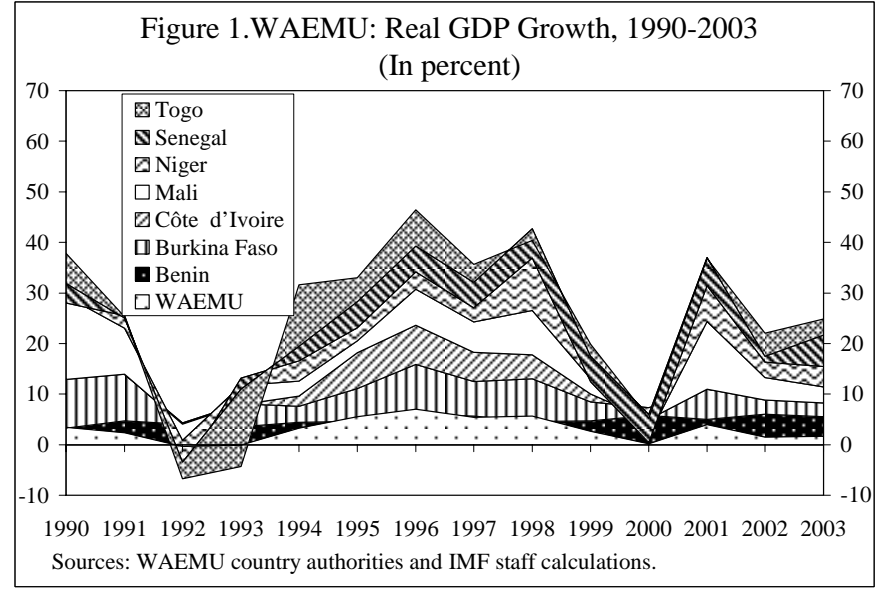

${ }^{10}$ Note that to calculate WAEMU's average inflation, the geometric average was used: $\bar{X}_{t}=\prod_{i=1}^{7} X_{i t}^{P_{i t}}$.

${ }^{11}$ The difference between the best and worst performer reached a high of 19.9 percentage points in 1993, and the disparity indicator versus the WAEMU average peaked at 2.9. 
resumption of growth, because the devaluation in itself had a substantial symmetrical impact on the CFA zone, markedly improving the member countries' competitiveness in a uniform manner. Recovery was also facilitated by restrictive demand policies and a range of structural and institutional reforms and was helped by an improvement in the terms of trade and favorable rainfall. The dispersion in growth rates narrowed to 4 percentage points in 1997, and the disparity index declined to an average of 0.6 in 1994-98. Since 1999, these broadly uniform economic gains gave way to a renewed heterogeneity. All countries were affected by the adverse spillover effects of Côte d'Ivoire's sociopolitical crisis. However, some member countries experienced reasonably robust growth whereas growth in some others was affected by political crises or the need to implement reforms. Thus, the dispersion in growth rates increased anew, and the disparity indicator widened to an average of 2.7 in 1999-03.

Gross savings and investment were also displayed different in the seven countries. Gross domestic savings were low in 1990-93. They rose markedly in 1994-98 in line with the resumption of growth and rehabilitation of public finances after the devaluation, but with significant contrasts among member countries (Appendix Table 2). In particular, savings declined in Niger and Togo because of unfavorable movements in the business cycle. As a result, the divergence indicator increased from 2.6 in the first subperiod to 7.3 in the second. Between 1999 and 2003, the average savings rate dipped somewhat, but the divergence indicator widened further, reflecting the uneven developments among countries. Driven by a private sector response to the improved economic environment, investment in the WAEMU rebounded from an average of 12.5 percent of GDP in 1990-93 to 16.4 percent of GDP in 1994-98 and then trailed off in 1999-2003, but with marked variations among countries (see Appendix Table 3).

In sum, neither the sources of GDP growth nor the uses indicate progress toward convergence. In particular, lower-income countries as a group did not experience an increase in their relative incomes, indicating an absence in gravitational pull from the WAEMU. ${ }^{12}$ Country-specific developments, policies, or both were the main explanatory variables for growth, with spillover effects (positive or negative) from WAEMU remaining low. ${ }^{13}$

Moreover, the role of labor mobility in attenuating differences in member country performances has ebbed, because the flows of migrants have diminished, or even been reversed, in recent years. One of the preeminent forces in the convergence of the WAEMU

\footnotetext{
${ }^{12}$ Wane (2004) found an absence of $\sigma$-convergence, suggesting that the wealth gap or inequality of per capita income between member countries has not narrowed over time.

${ }^{13}$ Doré, Anne, and Engemann (2003), using a nonsubjective weighted index of regional instability, found that the increase in regional instability caused by Côte d'Ivoire's political crisis had a negative effect on growth in its closest neighbors, but no significant effect on the WAEMU as a whole.
} 
economies used to be the free movement of its people within the zone ${ }^{14}$ and significant migration, in particular to Côte d'Ivoire. Rapid population growth and significant un- or underemployment in the zone-together with wide divergences in nominal wages between the coastal states and the landlocked countries, the shared language, and similar education systems-have drivemigration, allowing neighbors to gravitate toward each other, progressively forming a common labor market (Box 2). This factor mobility, which feeds large informal sectors, also significantly dampened wage pressures in WAEMU countries. Since early in 2000, Côte d'Ivoire's political crisis has been accompanied by nationalistic movements that are believed to have slowed down immigration and led non-Ivorian nationals, in particular Burkinabé, to return to their home countries.

\section{Box 2. WAEMU: Migratory Flows}

A breakdown by national origin of residents in WAEMU countries is not available. It is generally believed that net emigration originates for the most part in the landlocked Sahelian countries and moves toward the coastal states, particularly to Côte d'Ivoire. During 1960-90, Snerch (1994, p. 49), estimates the share of West Africa's overall population (excluding Nigeria) residing in a country other than the country of birth at 11 percent. Côte d'Ivoire experienced by far the highest immigration rates, followed by Cameroon, Senegal, and Nigeria. Immigration from neighboring countries was officially encouraged in Côte d'Ivoire in the 1960s and 1970s to develop the country's vast untapped agricultural potential, in particular the cocoa and coffee crops. Censuses in 1988 and 1996 estimated the non-Ivorian residents conservatively at around 30 percent of the population, of which 83 percent originated from other WAEMU countries (about 50 percent of the total came from Burkina Faso and 22 percent from Mali). In the 1990s, net annual immigration into Côte d'Ivoire was estimated at 0.4 percent of the resident population. A significant number of these nonnationals have been in Côte d'Ivoire for a generation or more and are fully integrated in the Ivorian economy. Senegal's 1988 census registered the share of foreign nationals at 3.1 percent of the total population, though the true percentage of foreigners is estimated to be well above that level. Given the very large weight of the nationals of The Gambia, only 4.3 percent of the foreign population reportedly originated from WAEMU countries (excluding Guinea-Bissau), of which two-thirds, from neighboring Mali. A study done in the mid-1990s in Burkina Faso estimated that 40 percent of the Burkinabé population is expatriate.

\footnotetext{
14 The free movement of people and the right of settlement is enshrined in Articles 91 and 92 of the WAEMU treaty.
} 


\section{Fiscal Developments}

Fiscal convergence has been the cornerstone of the efforts to promote economic integration in the WAEMU. After large fiscal imbalances plagued the WAEMU countries during 1990-93, the authorities realized that a high degree of credibility and stability in a monetary union characterized by a fixed exchange rate and endogenous money could be achieved only through prudent fiscal policies. This requires a strict harmonization and coordination of fiscal policies, while allowing some flexibility at the national level to offset the impact of exogenous shocks. A

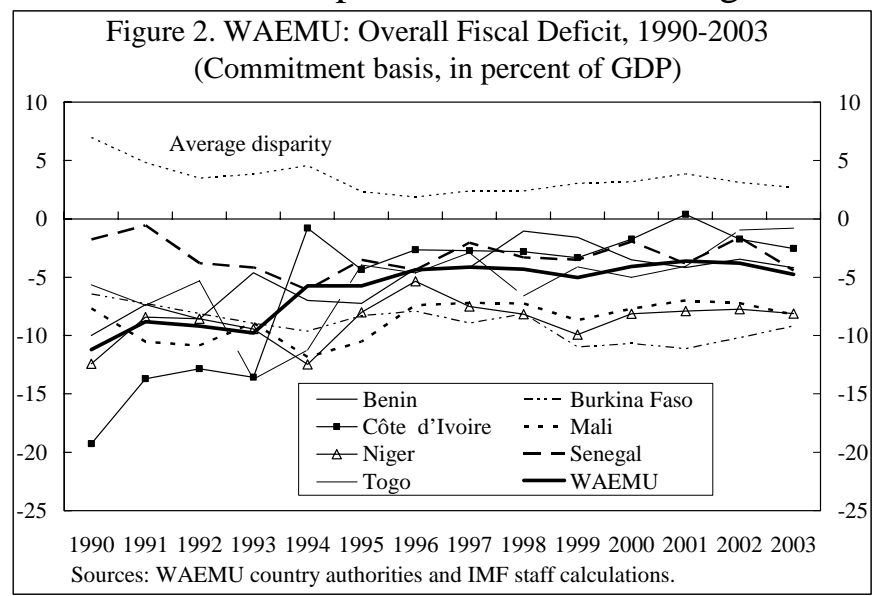
regional Convergence, Stability, Growth, and Solidarity Pact was adopted in December 1999 to strengthen convergence among the economies, notably through the use of a peer review process. The pact defines a set of convergence criteria ${ }^{15}$ which were to be met originally by the end of 2002. With the weakening of economic performance since 1999, the majority of countries were unable to meet the key convergence criteria by the original date, which was then moved forward to 2005. Also, the devaluation prompted a number of initiatives to promote fiscal integration and ensure a consistent incentive structure. Notably,

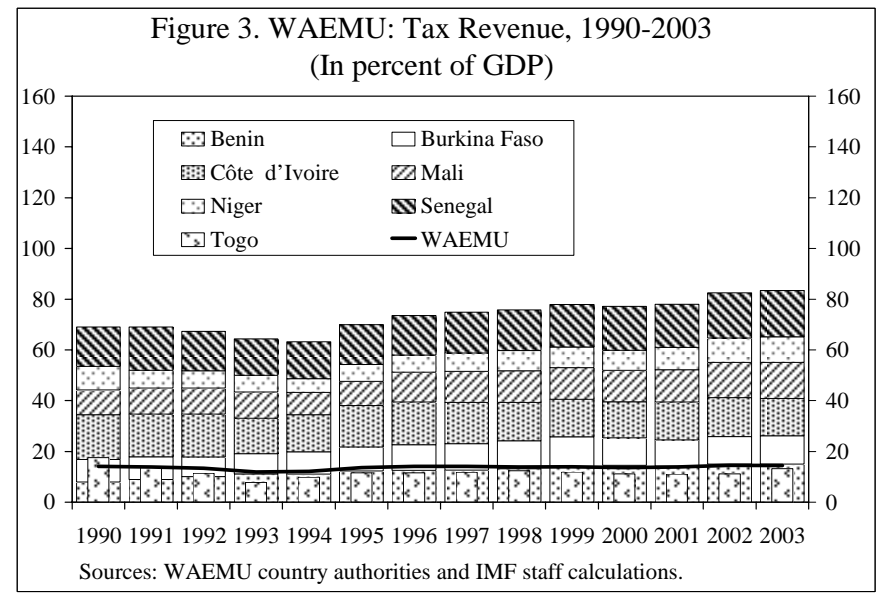
WAEMU member countries introduced a full-fledged customs union, a common external tariff (CET), which reduced the WAEMU unweighted average tariff from 19 percent in 1997

15 The pact calls for the observance of quantitative norms regarding four primary criteria: a basic fiscal balance (defined as total revenue-excluding grants, minus total expenditureexcluding foreign-financed investment) in surplus or zero, a ratio of public debt to GDP of close to 60 percent, the nonaccumulation of payments arrears, and an inflation rate of 3 percent or lower. The secondary criteria are a wage bill not to exceed 35 percent of tax revenue, a level of domestically financed investment that is at least 20 percent of tax revenue, an external current account deficit not to exceed 5 percent of GDP, and a minimum ratio of tax revenue to GDP of 17 percent. 
to about 12 percent in 2000, and the liberalization of intraregional trade. The value-added tax (VAT), excise taxes, the taxation of petroleum products, and the withholding taxes aimed at strengthening the taxation of the informal sector, were harmonized. Five directives were adopted to harmonize fiscal policy. Harmonized legislation pertaining to commercial activity, accounting, and disclosure was adopted.

Despite the political commitment at the regional level, progress toward fiscal convergence has generally remained limited. The 1994 devaluation and the ensuing implementation of domestic adjustment programs, together with debt relief, resulted, on average, in a marked improvement in the countries' public finance situations, with the overall deficit-to-GDP ratio about halved from 9.7 percent, on average, in 1990-93 to 4.6 percent, on average, in 19942003 (Appendix Table 4 and Figure 2). However, the coincident improvement in 1994-98 was reversed to a certain extent in 1999-2003, and the disparity indicator widened accordingly. ${ }^{16}$ In the same vein, the primary fiscal deficits improved, but heterogeneity increased, leading to a worsening of the disparity indicators (Appendix Table 5).

Homogeneity of tax revenue has improved. The structure of taxes is relatively similar in the WAEMU countries: ${ }^{17}$ indirect taxes ${ }^{18}$ represent, on average, about 40 percent of total tax revenue, custom duties about one-third, and direct taxes about one-fourth, with the landlocked Sahelian countries relying somewhat more on customs duties and correspondingly less on indirect taxes. Nonetheless, the low level of fiscal coordination and diverging fiscal systems, including the cost of competitive tax exemptions and concessions, still result in numerous negative fiscal spillover effects. ${ }^{19}$ Tax revenue improved gradually from about 13.3 percent of GDP on average between 1990-93 to just above 14 percent of GDP in 1999-2003 (Appendix Table 6 and Figure 3). Partly because of the harmonization efforts undertaken by WAEMU, homogeneity has improved steadily, with the average disparity indicators declining from 3.5 in 1990-93, to 2.9 in 1994-98 and to 2.3 in 1999-2003.

${ }^{16}$ Dore and Masson (2002) found that the fiscal stance worsened in some countries in 19982001 because of a terms of trade deterioration and unfavorable movements in the business cycle and that convergence stalled even when corrected for these factors.

${ }^{17}$ See also Nashashibi and Bazzoni (1994).

${ }^{18}$ Including VAT on imports and specific taxes on petroleum products.

19 See Rosenberg (1995). 
Expenditure shares in GDP have become significantly more homogenous across WAEMU countries. Adjustment programs undertaken after the devaluation reduced overall expenditure from close to 26 percent of GDP in 199093 to an average of about 20 percent of GDP in 1994-2003 (Appendix Table 7 and Figure 4). Moreover, expenditure compression was proportionally larger in the highest spenders, in particular in Côte d'Ivoire. As a result, the disparity indicator fell significantly from 6.8 in 1990-03 to 1.7 in 1999-2003. The same conclusion holds for current outlays (Appendix Table 8), but is being reversed when analyzing investment spending (Appendix Table 9 and Figure 5).

A large part of the expenditure adjustment after the devaluation has been to contain the government wage bill. WAEMU countries display a wide disparity in nominal average per capita salary levels, with the average civil service wages in Côte d'Ivoire about three times those in Niger in 1990-2003. Adjustment policies following the devaluation steadily reduced the government wage bill as a percentage of current outlays (Appendix Table 10 and Figure 6) and as a percentage of GDP (Appendix Table 11). These synchronous declines decreased wage inequality in WAEMU and the disparity indicators. Also, the ratio of the government wage bill to GDP in WAEMU now compares favorably with the average for sub-Saharan Africa (SSA). ${ }^{20}$

${ }^{20}$ For 1994-98, the average for WAEMU is 5.6 percent compared with 7.9 percent for SSA, and for 1999-03, 5.3 percent compared with 8.2 percent. 
In sum, although the homogeneity of countries' tax revenues and expenditures has improved, overall fiscal convergence has been limited. This is essentially explained by a highly divergent evolution in the level of investment outlays and in debt service costs. The former were influenced by country-specific policies, and the latter by the divergent schedules for achieving debt relief under the enhanced Heavily Indebted Poor Countries (HIPC) Initiative.

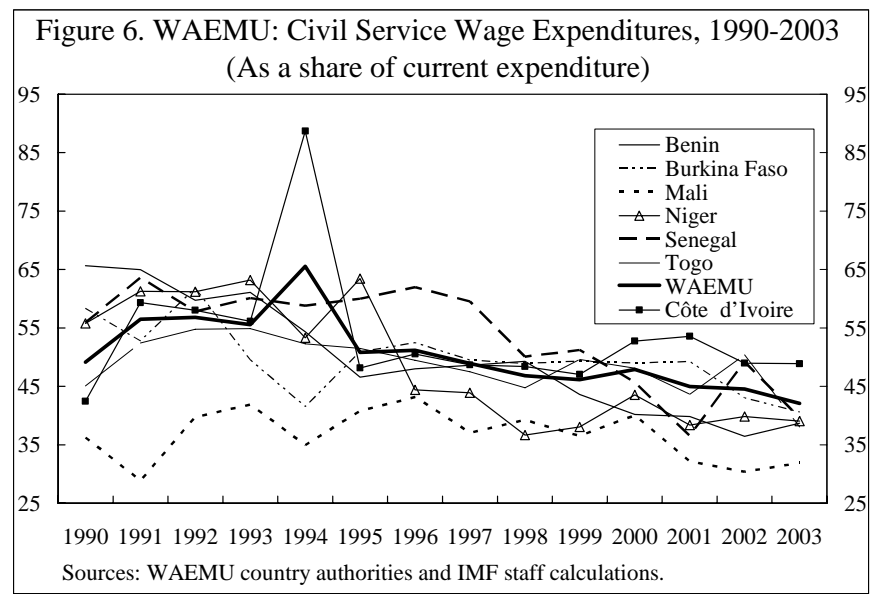
While harmonization of fiscal policies at the regional level has had a positive impact, the coordination of these policies has not been achieved in the absence of a mechanism to ensure that they do.

\section{Monetary Aspects of the Integration Process}

WAEMU's monetary policy is conducted at the regional level by the Banque Centrale des Etats de l'Afrique de l'Ouest (BCEAO), which holds the union's pooled international reserves. Its basic objectives are to preserve the credibility of the exchange rate, achieve its target level of foreign assets, restrain the inflation rate in member countries, and maintain monetary stability. Rother (1998) investigated the stability of regional monetary aggregates and their forecast performance. His money demand estimations suggested a stable relationship for narrow money and allowed him to conclude that if the BCEAO succeeds in maintaining financial stability, it can continue conducting monetary policy in line with the fixed exchange rate system. Bank supervision is also conducted at the regional level, with the responsibility resting with the regional Banking Commission, established in 1990.

The BCEAO seeks to control domestic credit expansion in the region through the use of indirect monetary policy instruments. The policy instruments available to the BCEAO are the discount rate mechanism, a repurchase agreement facility (pension window), minimum reserve requirements, and the issuance of central bank bills. The BCEAO mainly relies on reserve requirements and the central bank standing facilities, and does not typically use its discretionary instruments (central bank bills). Also, it uses reserve requirements on a differentiated basis to account for their different price and credit developments and liquidity positions. Since 2002, the financing of government fiscal deficits has been shifted from central bank direct advances to the issuance of securities on the regional capital market. The low volume government securities issued so far has not helped to mop up the excess bank liquidity. However, it has promoted the development of the capital market and has accustomed the public to saving through the securities market. 
The banking system has been plagued by a significant monetary overhang, a lack of competition at the regional level, and the absence of an active interbank market. These deficiencies result in significant inefficiencies in the banking system at the regional level, which hinder the channeling of funds from very liquid banks in some member countries to member in other countries where demand for credit is relatively strong. Nonetheless, banks have started competing regionally for the business of the largest and most creditworthy corporations. The efficiency of the banking system has been enhanced somewhat by the introduction of a single, zonewide licensing agreement for banks in the WAEMU. Also, the regional payments system has been overhauled to facilitate interbank transactions, notably through the establishment of a cross-border real-time gross settlement system. As a result, interbank trading has picked up somewhat, but has mostly remained limited to trading between subsidiaries of banking groups that operate throughout the region.

A number of initiatives have aimed at deepening financial integration. Concerning regulatory frameworks, the new business law adopted in the context of the regional organization for harmonization of business laws (OHADA) has been implemented in all member states. Microfinance institutions have grown in importance and operate under the Parmec Law, developed by the BCEAO and implemented in all the WAEMU countries. Also, a regional credit risk agency and a development bank (Regional Solidarity Bank) have been set up. However, the WAEMU countries still need to develop a more diversified range of financial institutions and instruments to fully exploit investment and growth opportunities. Aside from services provided by commercial banks, there is a need to develop at the regional level, appropriate financing mechanisms for the agricultural sector and for small and medium-sized enterprises through cooperative credit associations. Development of collective savings institutions (mutual funds), mortgage and housing finance institutions, and leasing and venture capital firms should also be encouraged.

\section{INTRAREGIONAL TRADE AND COMPETITIVENESS}

\section{A. Characteristics of Trade}

The WAEMU countries have become more open to international trade. The ratio of their external trade to GDP averaged 61 percent during 1990-2003 and has risen steadily since 1994 (Appendix Table 12). The most significant improvement in openness for all countries in the region was the 1994-98 period. For the 1999-2003 period, although average tariff rates declined with the introduction of the CET in 2000, further increases in trade openness (from the 1994-98 period) were only experienced by three member countries (Côte d'Ivoire, Mali, and Togo). Despite the increased openness, WAEMU remains a very small player in global trade, with exports and imports representing on average 0.12 and 0.15 percent, respectively, of world exports and imports during 1990 and 2003. 
A large share of WAEMU countries' exports is concentrated in a few primary commodities, making them highly vulnerable to terms of trade shocks, caused by large swings in the world prices of their commodity exports. ${ }^{21}$ The share of the two main commodities in total exports averaged 47.5 percent for WAEMU, with a high of close to 83 percent for Benin and a low of about 41 percent for Senegal (Appendix Table 13). The average ratios remained relatively stable at about 50 percent in the 1990-93 and 1994-98 subperiods, indicating that the WAEMU's renewed competitiveness after the 1994 devaluation did not result in a diversification of the export base away from a limited number of primary commodities. However, the concentration ratio fell to about 43 percent in the 1999-2003 subperiod. The countries with the lowest concentration ratio (Côte d'Ivoire, Senegal, and Togo) have the highest level of openness (Figure 7) and increased their openness over time
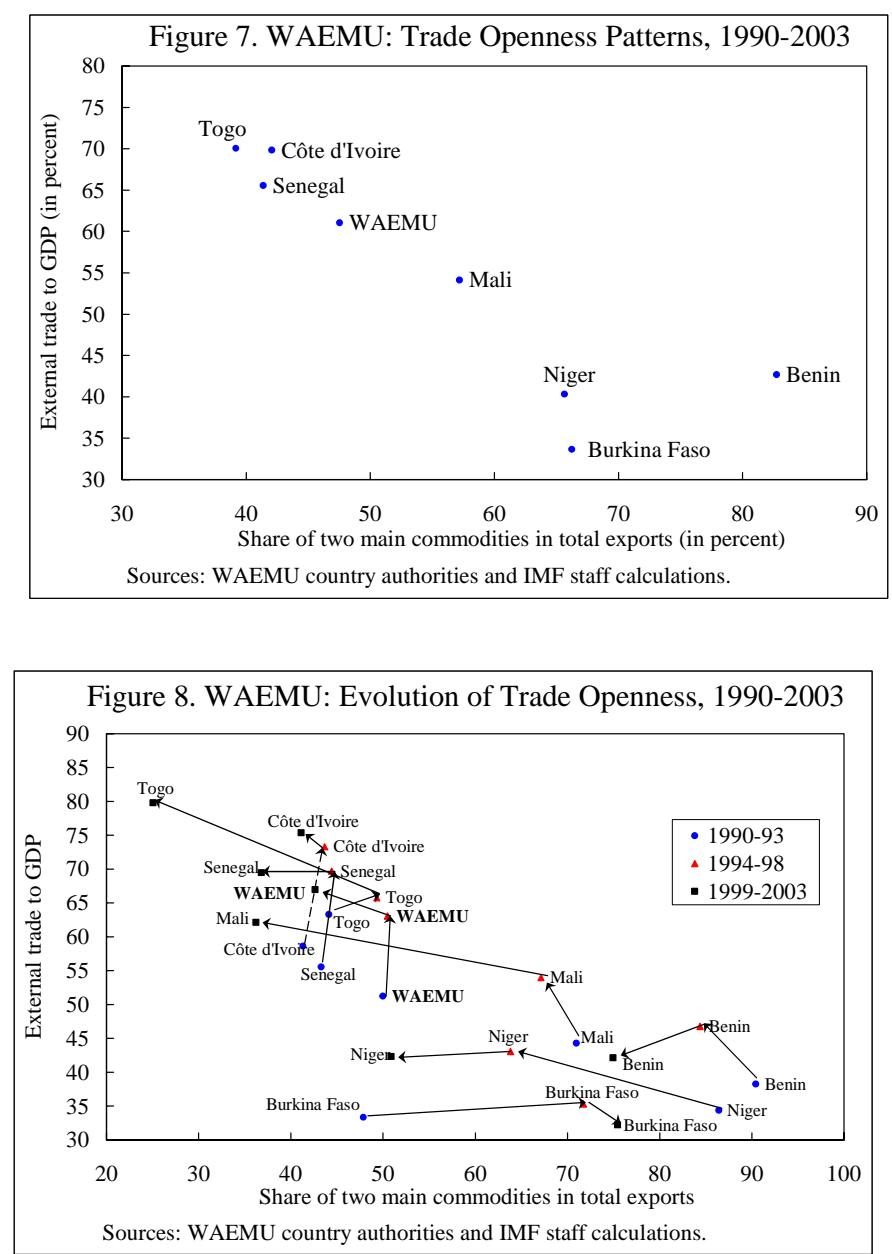
(Figure 8). The correlation between openness and concentration is -0.88 for the whole sample and becomes even stronger for the period 1999-2003 (correlation coefficient of -0.90), suggesting that low concentration (that is, greater diversification) has been associated with more openness.

${ }^{21}$ Kose and Riezman (2001) report that the variations in the prices of exported commodities account for roughly half of the output fluctuations in a model calibrated to represent a typical African economy. 
Trade within the WAEMU is distinctive in a number of ways. On the export side, Côte d'Ivoire and Senegal direct a relatively large part of their overall exports (11 percent and 6.5 percent, respectively, during 1990 2003) to the WAEMU area (Appendix Table 14 and Figure 9$)^{22}$ and are by far the biggest suppliers of goods to the zone (accounting for about 74 and 14 percent, respectively, of intrazone exports-Appendix Table 15 and Figure 10). As noted in European Commission (1997), the landlocked WAEMU countries export primary commodities to the other union members. Benin and Togo rely on transit trade, whereas Côte d'Ivoire and Senegal invert their trade patterns between intrazone exports and exports to the rest of the world. Although Côte d'Ivoire and Senegal essentially export primary commodities to the rest of the world, they export manufactured goods to the other WAEMU countries. As to imports, the landlocked countries buy a large share of their overall imports from within the zone, whereas Côte d'Ivoire and Senegal buy very little from it (Appendix Table 16 and Figure 11). As a result, the combined share of Burkina Faso and Mali represents about 63 percent of intraregional imports (Appendix Table 17 and Figure 12).
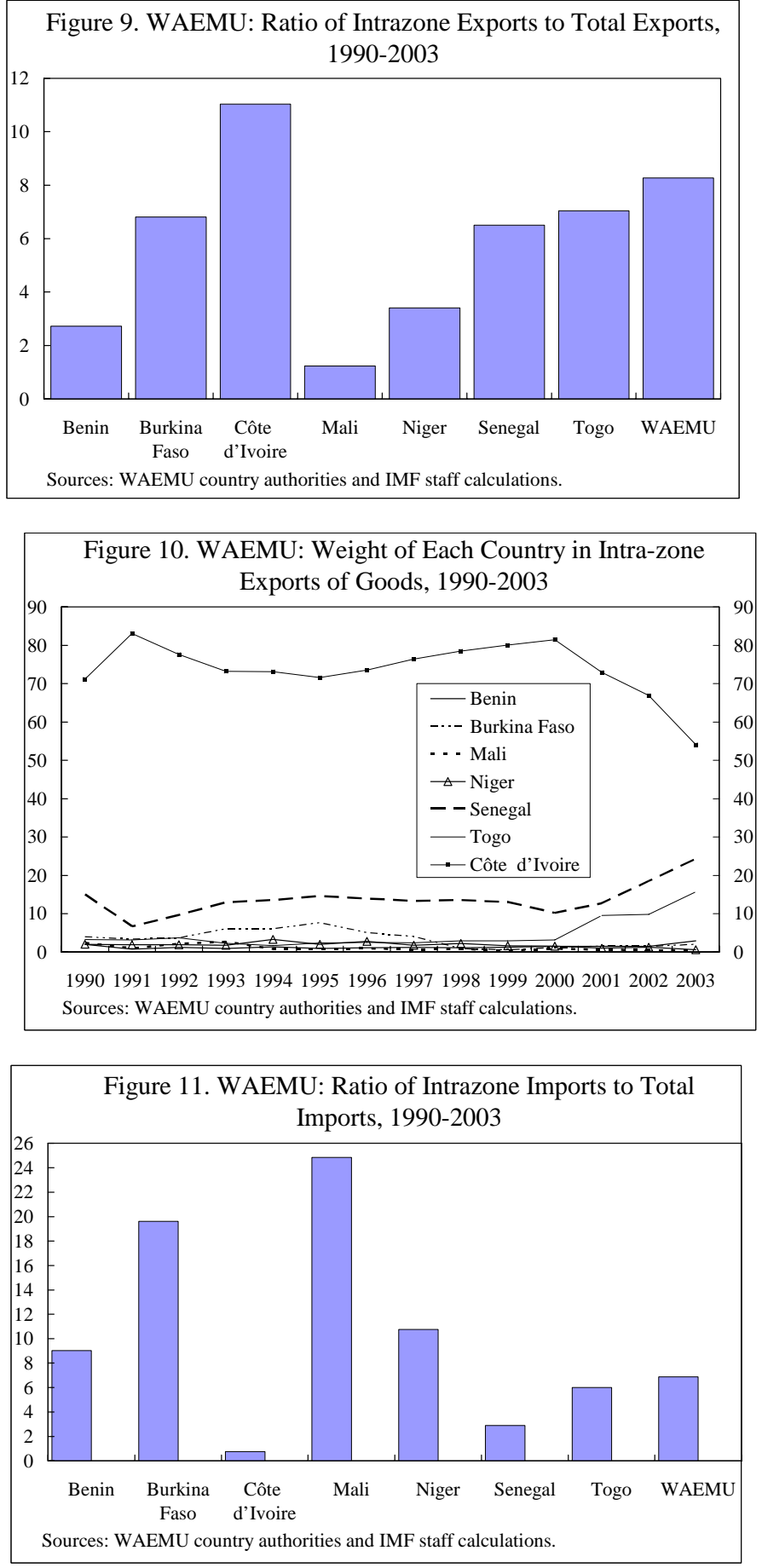

${ }^{22}$ The high share for Togo started from 2001 onward and reflects a boom in transit trade following trade disruptions in Côte d'Ivoire due to the political upheaval there. 
The level of recorded intraregional trade has remained low despite progress on the integration front since 1994 and the introduction of preferential trade arrangements within the WAEMU in $2000 .^{23}$ During 1990-2003, intraregional exports and imports averaged 8.3 and 6.9 percent, respectively, of total exports and imports (Appendix Tables 14 and 15). After declining in 1990-03, intra-regional trade grew from 1994 onward, reflecting changes in consumption patterns induced by

Figure 12. WAEMU: Weight of Each Country in Intrazone Imports of Goods, 1990-2003

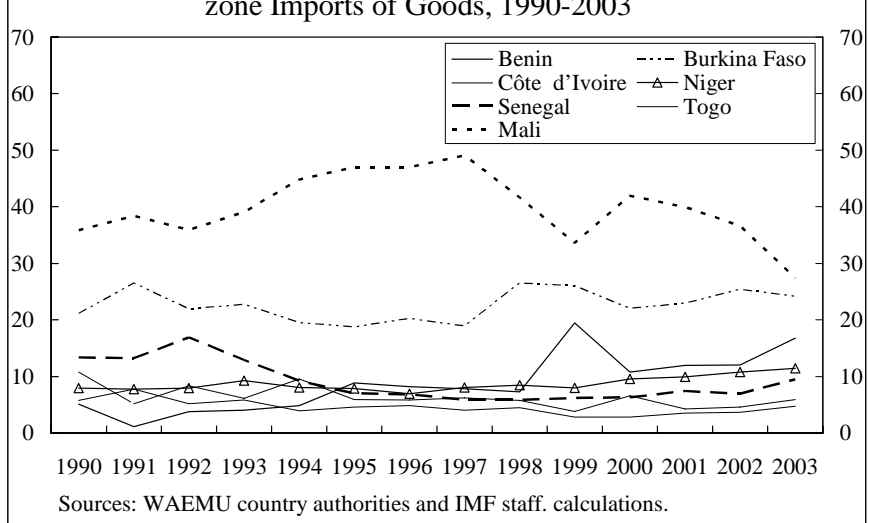
relative price changes after the devaluation (Appendix Tables 18 and 19). Intra-regional trade declined in 2000, notably because of a significant retrenchment of Côte d'Ivoire's trade owing to the sociopolitical crisis, but began to grow again in 2001, helped by the elimination of tariffs on intraregional trade in 2000. The scope for an expansion of intraregional trade remains limited, however, because of the region's low consumption of its primary commodities, the similarity of agricultural products and manufactured goods produced, and major bottlenecks in the regional transportation network and marketing arrangements that raise export costs.

Although there is no conclusive empirical evidence of a link between regional trade creation and welfare gains, the establishment of a reinforced economic space and strategic complementarities among WAEMU countries could yield clear benefits. Trade theory indicates that trade creation is more likely to dominate trade diversion when a customs union is set up among countries that had already been able to trade before. ${ }^{24}$ The landlocked countries, in particular, could offset the drawback of having a very small industrial basis by better exploiting their lower wage costs and comparative advantages in many areas (such as textiles, animal husbandry, leather, fruits and vegetables) ${ }^{25}$ The coastal states, on the other hand, and particularly Côte d'Ivoire and Senegal, could be more favorable to intraregional purchases.

${ }^{23}$ Informal cash-based cross-border trade is very important among WAEMU member countries, and recorded intraregional trade must be interpreted with caution.

${ }^{24}$ See, for instance, Halevy and Kleiman (1995).

${ }^{25}$ See also Commission of the European Union (1997), pp. 20-40. 


\section{B. Competitiveness}

The CFA franc zone countries adopted the fixed exchange rate regime in 1948. During the second half of the 1980s and in the early 1990s, these countries experienced a prolonged deterioration of their terms of trade, a steep rise in their labor costs, and a nominal appreciation of the French franc against the U.S. dollar, all of which resulted in an overvalued exchange rate followed by the 1994 devaluation of the CFA franc. ${ }^{26}$ The devaluation, combined with the structural adjustment programs supported by the IMF and the World Bank and prudent monetary policies, was successful in returning the WAEMU countries' GDP to positive growth rates, controlling inflation in the region as a whole, and substantially strengthening their competitiveness. However, more recently, on the basis of traditional exchange rate and competitiveness indicators, some of the competitiveness gains appear to have been lost, while structural policies, particularly to increase labor productivity and lower production costs, have stumbled.

We examine the external competitiveness of the WAEMU based on a variety of indicators for which data are available. In particular, we focus the analysis on (i) "traditional" measures of competitiveness based on various definitions of the real effective exchange rates (consumer price index (CPI)-based, internal, cost-based); (ii) indicators of profitability; and (iii) indicators of market shares.

\section{Evolution of the CPI-based real effective exchange rate (REER)}

The 1994 devaluation of the

CFA franc corrected the overvaluation of the currency and improved the region's external competitiveness. Since then, the REER appreciated cumulatively by about 12 percent through 2001 and by a further 8 percent during 2002-03 on a yearly basis, with the latest

\begin{tabular}{|c|c|c|c|}
\hline \multicolumn{4}{|c|}{$\begin{array}{l}\text { WAEMU: Average Annual Change in Real Effective Exchange Rate and Its Components } \\
\text { (In percent) }\end{array}$} \\
\hline & $\begin{array}{l}\text { Jan } 1994- \\
\text { Dec } 1998\end{array}$ & $\begin{array}{l}\text { Jan 1999- } \\
\text { Dec 2000 }\end{array}$ & $\begin{array}{l}\text { Jan 2001- } \\
\text { Dec 2003 }\end{array}$ \\
\hline \multicolumn{4}{|l|}{ Percentage change } \\
\hline Real effective exchange rate & 38.2 & -8.7 & 8.6 \\
\hline Nominal effective exchange rate & 13.2 & -8.1 & 9.0 \\
\hline Relative price index & 27.8 & -0.2 & -1.3 \\
\hline \multicolumn{4}{|l|}{ Cumulatively } \\
\hline Real effective exchange rate & 33.0 & -8.7 & 10.5 \\
\hline Nominal effective exchange rate & 12.7 & -8.2 & 10.3 \\
\hline Relative Price Index & 24.9 & 0.8 & -1.7 \\
\hline
\end{tabular}
appreciation attributable to the strengthening of the euro, to which the CFA franc is pegged. ${ }^{27}$ By end-2003, the regional REER was about 76 percent of its predevaluation level.

${ }^{26}$ The CFA franc devaluation of 50 percent against the French franc in January 1994 was the only change in the exchange rate peg.

${ }^{27}$ Unless noted otherwise, REER will refer to the CPI-based REER measured as the ratio of domestic to foreign CPIs. 
The evolution of WAEMU's REER in the aftermath of the devaluation can be divided into three phases: (i) January 1994 to December 1998, when the REER appreciated rapidly as a result of the surge in domestic wages and prices following the devaluation; (ii) a short period of depreciation between January 1999 and December 2000, driven by the decline in the terms of trade resulting from declines in key export commodity prices and an increase in oil prices (Figure 13) as well as the slowdown in the world economy; and

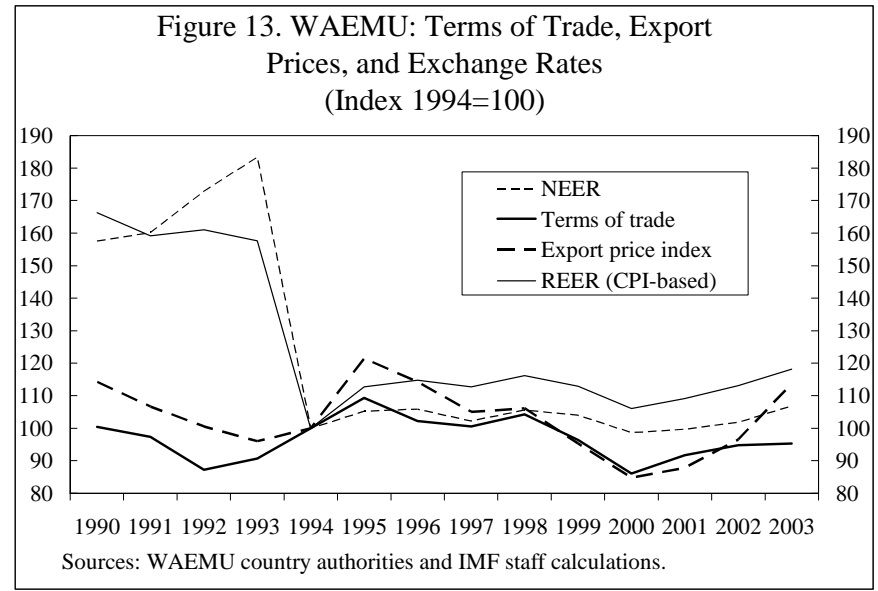
(iii) January 2001 to the present, with an appreciating REER, reflecting mainly the strengthening of the euro against the U.S. dollar. Looking at the member countries of the WAEMU, we observe that their respective REERs follow, in principle, the regional average. Benin has experienced the highest appreciation since the 1994 devaluation and Senegal the lowest, with their appreciation by end-2003 standing at between 68.4 percent (Senegal) and 87.8 percent (Benin) of their predevaluation levels.

\section{Evolution of other REER measures}

We estimate two other measures of the REER: the internal real effective exchange rate (IRER) measured as the ratio of nontradables to tradable goods; and the cost-based REER. ${ }^{28}$

The IRER, which is measured as the ratio of the prices of nontraded goods $\left(P_{N T}\right)$ to those of tradable goods $\left(P_{T}\right)$, can be an appropriate measure of competitiveness for small economies, where the cost of production is reflected in the price of nontradables goods and the price of imports is

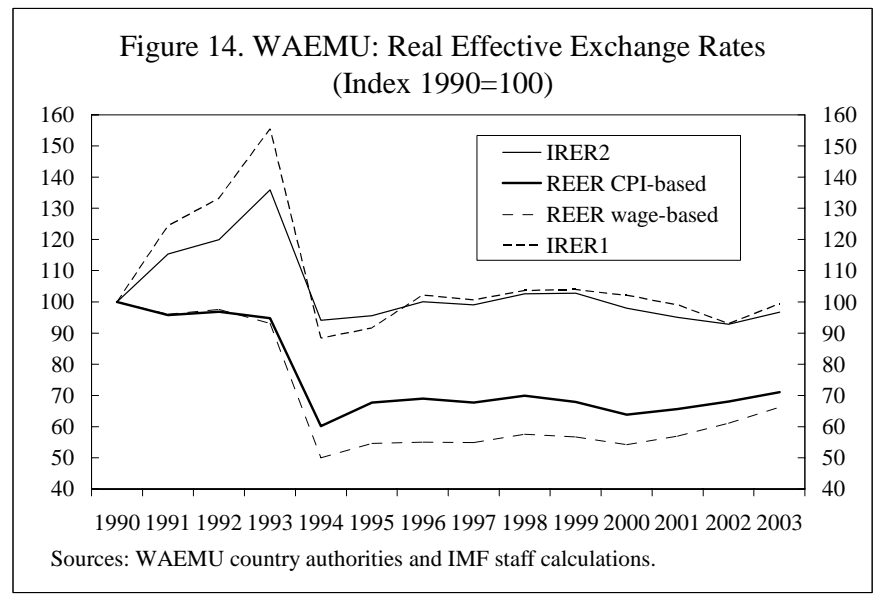

${ }^{28}$ The latter is calculated as the CPI-based REER multiplied by the real wage index-that is, the nominal wage index deflated by the CPI. 
determined in the world market. The difficulty in measuring the IRER is the lack of a straightforward definition of tradable and nontradables goods. For a robustness check of our results, we use two different approaches presented in the literature. ${ }^{29}$

Figure 14 plots all four measures of the REER. First, we observe that the IRER fluctuations in the WAEMU region followed that of the CPI-based REER, but with wider amplitude. In particular, there was a steady real appreciation of the REER from the devaluation in 1994 through 1999, attributable to larger increases in the prices of nontraded goods than in the prices of tradable goods, which cut into the profits of the tradable sector and thereby hampered the much-needed export diversification of the economy. ${ }^{30}$ Second, the labor-costbased REER appears to have remained below the CPI-based REER and the IRER; in particular, the labor-cost-based REER depreciated more than the CPI-based REER after the 1994 devaluation and has since remained at lower levels. These results might suggest that the region's competitiveness in international markets seems better when cost-based REERs rather than CPI-based REERs are used, and worse when IRER is used.

\section{Market shares and profitability}

Since 2000, WAEMU export market shares to the world and to the European Union (EU) appear to be increasing, and decreasing for Africa and the United States while intraregional exports have been expanding (Figure 15). In terms of the overall evolution of market shares to the world since the 1994 devaluation, WAEMU shares have actually fallen to all groups except to Africa.

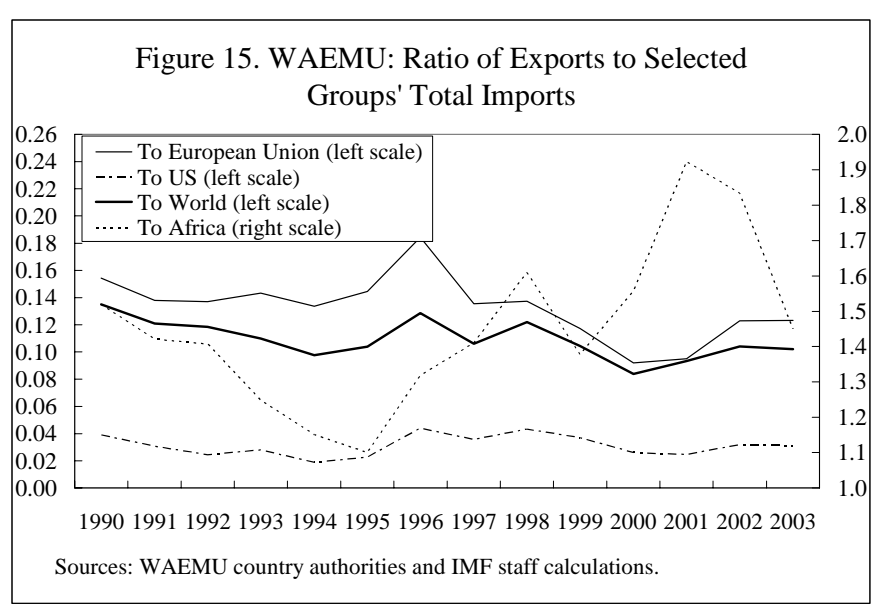

${ }^{29}$ Details on the calculation of the IRER using two alternative methodologies are presented in Appendix II.

${ }^{30}$ Specifically, from 2001 to 2003 the increase in the $P_{N T} / P_{T}$ ratio was attributed to a decline in $\mathrm{P}_{T}$ (-2.1 percent on average) and a 2.1 percent increase in the $P_{N T}$. For the period 19982003, the increase in the $P_{N T} / P_{T}$ ratio was attributed to the faster increase in $P_{N T}$ versus $P_{T}$ (1.9 percent and 0.5 percent, respectively). 
Looking at Figure 13, terms of trade and export index improvements for the WAEMU region indicate a potential improvement of profitability. We investigate profitability further by constructing two direct measures of profitability: the ratio of the export price index to tertiary GDP deflator and the export price index to wages deflator. Both of these indices of profitability (Figure 16) show a net decline since 2001-02, and a small overall increase since the 1994

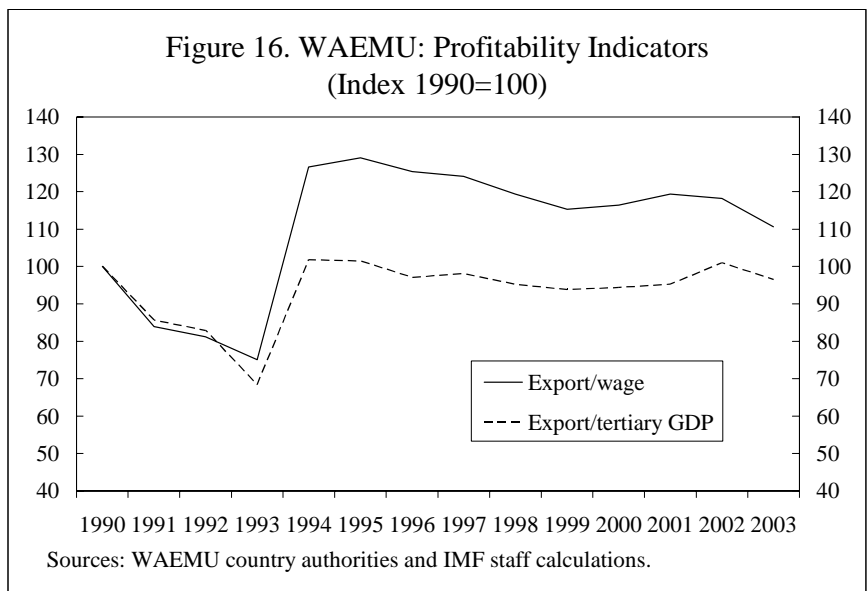
devaluation.

In summary, the analysis of external competitiveness has yielded some evidence of an erosion of WAEMU countries' competitiveness. Measures of the real exchange rates indicate that these countries have lost some of the competitiveness gains from the 1994 devaluation, export shares have remained stagnant and in some cases have been falling, and other competitiveness indicators point to continued structural rigidities in the region, ${ }^{31}$ highlighting the need to continue to monitor the developments in competitiveness more closely.

\section{PROSPECTS FOR FURTHER INTEGRATION}

While the fixed currency peg contributed to price stability, WAEMU's progress in economic integration has been disappointing. WAEMU countries have a host of things in common but also differences. They share historical ties, a common official language, similarities in legal frameworks and administrative structure, and, indeed, a common currency and some degree of financial integration. Efforts to alleviate the important diverging trends linked, inter alia, to level of income, resource endowment, population size, and lack of complementarities, have been insufficient to foster a common economic sphere.

The political will of member states will have to be the main factor to further integration. Integration has been driven so far by the desire to complement the monetary union by an economic union. A stronger political drive will be needed, however, to dismantle remaining trade barriers, eliminate remaining state trading monopolies, improve the transportation system and intraregional communication networks, boost the regional cooperation in the

${ }^{31}$ These include rigidities in the factor markets, which raise factor costs; the vulnerability of the domestic price level to agricultural production fluctuations; low diversification of base production and exports; and a lack of implementation of regional integration programs, notably in infrastructure and telecommunications. 
power sector, and harmonize public procurement policies. To increase FDI, improved economic governance and transparency might be crucial. ${ }^{32}$ Also, to encourage migration, which has been one of the strongest forces of integration, all formal or informal administrative restrictions should be abolished for WAEMU nationals within the union, together with a facilitation of cross-border transfers of pension rights and social security benefits.

Strengthening competitiveness is a key objective of the WAEMU countries. In particular, emphasis should be placed on: (i) the pursuit of structural reform policies to boost labor productivity, reduce excessive factor costs, and diversify the base of production and exports of the economies; (ii) the reduction of factor costs through the improvement of access to new technologies, the implementation of integration programs in the WAEMU region, notably in the road infrastructure, telecommunications and energy, as well as those facilitating interregional trade; (iii) creating the conditions for a further increase in domestic and foreign private investment in all sectors of economic activity (especially in the non-oil sector) including by deepening the judicial, legal, and institutional framework.

\section{Conclusions}

Although more than 10 years have elapsed since the WAEMU was established, the eight WAEMU countries and their citizens are not yet fully integrated. Growth has been driven foremost by country-specific developments, with few spillover effects from the WAEMU region as a whole. Labor mobility has slowed, and despite the institutional efforts, fiscal convergence has been disappointing. Furthermore, the expansion of intraregional trade has remained modest, and competitiveness has eroded. To reverse these trends and complete the creation of a full-fledged economic union, the eight countries will need significantly stronger political drive to overcome the narrowness of their economies and lessen structural rigidities.

32 Rogoff and Reinhart (2003). 


\section{Appendix I. Calculation of the Internal Real Exchange Rate}

The internal real exchange rate (IRER) is calculated as the ratio of the domestic prices of nontradables to that of tradable goods. To categorize the consumption bundle into tradable and nontradables goods, we use two proxies described in the literature.

\section{First proxy: IRER}

Using the definition of IRER, ${ }^{33}$

$$
\operatorname{IRER}=P_{N T} / P_{T}
$$

Also, the consumer price index (CPI) can be defined as a weighted average of the prices of tradable and nontradables goods. Let $z$ be the share of tradable goods in the CPI basket. Then,

$$
C P I=\left(P_{T}\right)^{y}\left(P_{N T}\right) .^{1-z}
$$

Reorganizing (2) and substituting (1), the IRER can be expressed as

$$
I R E R_{1}=\left(C P I / P_{T}\right) .^{1 /(1-z)}
$$

Import prices were used as a proxy for prices of tradable goods, and the share of imported consumption goods in total private consumption was used as a proxy for $z$.

\section{Second proxy: IRE $R_{2}$}

The second proxy was based on the three-good model of Devarajan, Lewis, and Robinson (1993). ${ }^{34}$ The model categorizes the economy as producing a domestic good and an exported good. Aggregate income is given by:

$$
p_{y} Y=p_{d} D+p_{x} X,
$$

\footnotetext{
33 The same methodology was used in Hernández-Catá and others (1998) and is also discussed in detail in Hinkle and Nsengiyumva (1997).

${ }^{34}$ The domestically produced good, the imported consumption good, and the export good.
} 
where $p_{y}, p_{d}$ and $p_{x}$ are the GDP deflator, the price of the domestically produced good and the price of the export good, respectively; and, $Y, D$, and $X$ are total output, output of the domestically produced good, and the output of the exported good (all in real terms), respectively.

Dividing equation (4) by $Y$ and denoting the share of exports as $S_{x}$ yields:

$$
p_{y}-p_{x} S_{x}=p_{d} D / Y=p_{d}(Y-X) / Y
$$

Rearranging equation (5) yields

$$
p_{d}=\left(P_{y}-S_{x} P_{x}\right) /\left(1-S_{x}\right)
$$

Then, $I R E R_{2}$ can then be calculated using the standard definition $\left(P_{N T} / P_{T}\right)$, and using import prices as a proxy for the price of tradable goods:

$$
\operatorname{IRER}_{2}=\left[\left(P_{y}-S_{x} P_{x}\right) /\left(1-S_{x}\right)\right] / P_{T}
$$




\section{Appendix II. WAEMU Indicators}

Table 1: WAEMU: Real GDP Growth

\begin{tabular}{|c|c|c|c|c|c|c|c|c|c|c|c|c|c|c|c|c|c|c|}
\hline & 1990 & 1991 & 1992 & 1993 & 1994 & 1995 & 1996 & 1997 & 1998 & 1999 & 2000 & 2001 & 2002 & 2003 & 1990-2003 & $1990-3$ & 1994-8 & 1999-2003 \\
\hline Benin & 3.2 & 4.7 & 4.0 & 3.5 & 4.4 & 4.6 & 6.0 & 5.7 & 4.6 & 4.7 & 5.8 & 5.0 & 6.0 & 5.5 & 4.8 & 3.9 & 5.0 & 5.4 \\
\hline Burkina Faso & 10.8 & 9.2 & 0.3 & 4.6 & 3.2 & 6.5 & 9.9 & 6.8 & 8.5 & 3.7 & 1.5 & 5.9 & 4.4 & 6.5 & 5.8 & 6.1 & 7.0 & 4.4 \\
\hline Côte d'Ivoire & -1.1 & 0.0 & -0.2 & -0.2 & 2.0 & 7.1 & 7.7 & 5.7 & 4.8 & 1.6 & -2.3 & 0.1 & -1.6 & -3.8 & 1.4 & -0.4 & 5.4 & -1.2 \\
\hline Mali & 16.5 & 9.1 & -3.2 & 3.8 & 3.0 & 2.4 & 7.1 & 6.1 & 8.7 & 3.0 & -3.2 & 13.3 & 4.4 & 3.2 & 5.2 & 6.3 & 5.4 & 4.0 \\
\hline Niger & -1.3 & 2.5 & -6.5 & 1.4 & 4.0 & 2.6 & 3.4 & 2.8 & 10.4 & -0.6 & -1.4 & 7.1 & 3.0 & 4.0 & 2.2 & -1.0 & 4.6 & 2.4 \\
\hline Senegal & 3.9 & -0.4 & 2.2 & -2.2 & 2.9 & 5.2 & 5.1 & 5.0 & 5.7 & 5.0 & 5.6 & 5.6 & 1.1 & 6.3 & 3.6 & 0.8 & 4.8 & 4.7 \\
\hline Togo & 5.9 & 0.2 & -3.3 & -15.3 & 12.2 & 4.7 & 7.1 & 3.5 & -2.3 & 2.4 & -0.8 & -0.2 & 4.6 & 3.1 & 1.4 & -3.4 & 4.9 & 1.8 \\
\hline WAEMU & 3.4 & 2.4 & -0.4 & -0.1 & 3.2 & 5.5 & 7.0 & 5.4 & 5.7 & 2.6 & 0.2 & 4.0 & 1.5 & 1.7 & 3.0 & 1.3 & 5.4 & 2.0 \\
\hline Average disparity & 5.7 & 3.7 & 2.7 & 4.2 & 2.3 & 1.7 & 1.6 & 1.0 & 2.7 & 1.6 & 3.4 & 4.3 & 2.8 & 4.4 & 1.7 & 2.9 & 0.6 & 2.7 \\
\hline
\end{tabular}

Table 2: WAEMU: Share of Gross Domestic Savings in GDP

\begin{tabular}{|c|c|c|c|c|c|c|c|c|c|c|c|c|c|c|c|c|c|c|}
\hline & 1990 & 1991 & 1992 & 1993 & 1994 & 1995 & 1996 & 1997 & 1998 & 1999 & 2000 & 2001 & 2002 & 2003 & $1990-2003$ & $1990-3$ & 1994-8 & 1999-2003 \\
\hline $\begin{array}{l}\text { Benin } \\
\end{array}$ & 4.3 & 4.4 & 2.5 & 3.5 & 7.9 & 8.5 & 7.6 & 5.6 & 6.6 & 4.8 & 6.0 & 6.5 & 4.7 & 6.1 & 5.6 & 3.7 & 7.2 & 5.6 \\
\hline Burkina Faso & 5.6 & 7.2 & 9.3 & 8.9 & 9.0 & 8.3 & 5.9 & 9.0 & 8.7 & 2.9 & 2.4 & 4.9 & 5.3 & 6.4 & 6.7 & 7.8 & 8.2 & 4.4 \\
\hline Côte d'Ivoire & 11.3 & 10.4 & 9.2 & 13.3 & 24.9 & 22.9 & 20.8 & 22.8 & 19.7 & 21.3 & 17.6 & 18.7 & 26.4 & 24.4 & 18.8 & 11.0 & 22.2 & 21.7 \\
\hline Mali & 9.1 & 9.2 & 4.1 & 9.3 & 14.1 & 12.1 & 6.4 & 14.1 & 11.8 & 5.9 & 11.6 & 17.5 & 19.0 & 17.3 & 11.5 & 7.9 & 11.7 & 14.3 \\
\hline Niger & 4.2 & 2.8 & 5.8 & 3.9 & 0.0 & -0.2 & 2.3 & 3.0 & 2.8 & 3.9 & 3.5 & 4.4 & 4.0 & 4.8 & 3.3 & 4.2 & 1.6 & 4.1 \\
\hline Senegal & 7.9 & 5.9 & 7.4 & 5.5 & 11.8 & 11.1 & 12.2 & 9.2 & 10.9 & 12.2 & 8.6 & 8.6 & 9.1 & 8.5 & 9.2 & 6.7 & 11.0 & 9.4 \\
\hline Togo & 13.9 & 6.7 & 4.8 & -0.5 & 7.9 & 9.1 & 3.9 & -2.2 & 2.8 & 3.2 & -2.1 & -1.5 & -2.4 & 0.8 & 3.2 & 6.2 & 4.3 & -0.4 \\
\hline WAEMU & 8.9 & 7.8 & 7.3 & 8.8 & 15.7 & 14.7 & 13.1 & 14.1 & 13.2 & 12.9 & 10.8 & 12.2 & 15.3 & 14.3 & 12.1 & 8.2 & 14.2 & 13.1 \\
\hline Average disparity & 2.9 & 2.5 & 2.2 & 4.3 & 8.3 & 7.5 & 7.1 & 8.3 & 6.2 & 7.9 & 6.4 & 6.7 & 10.1 & 8.6 & 6.0 & 2.6 & 7.3 & 7.8 \\
\hline
\end{tabular}

Table 3: WAEMU: Share of Gross Investment in GDP

\begin{tabular}{|c|c|c|c|c|c|c|c|c|c|c|c|c|c|c|c|c|c|c|}
\hline & 1990 & 1991 & 1992 & 1993 & 1994 & 1995 & 1996 & 1997 & 1998 & 1999 & 2000 & 2001 & 2002 & 2003 & $1990-2003$ & $1990-3$ & $1994-8$ & 1999-2003 \\
\hline Benin & 14.2 & 14.5 & 13.8 & 15.4 & 15.8 & 19.6 & 17.0 & 18.4 & 17.0 & 17.5 & 18.9 & 19.2 & 17.8 & 18.1 & 16.9 & 14.5 & 17.6 & 18.3 \\
\hline Burkina Faso & 18.6 & 20.1 & 21.8 & 21.8 & 20.4 & 21.8 & 21.5 & 23.4 & 22.8 & 17.7 & 18.2 & 18.8 & 18.4 & 18.9 & 20.3 & 20.6 & 22.0 & 18.4 \\
\hline Côte d'Ivoire & 6.7 & 7.4 & 5.7 & 9.8 & 13.7 & 15.6 & 12.1 & 14.4 & 13.3 & 13.1 & 10.6 & 11.0 & 10.4 & 10.0 & 11.0 & 7.4 & 13.8 & 11.0 \\
\hline Mali & 22.2 & 22.1 & 18.9 & 21.6 & 30.6 & 31.1 & 20.9 & 23.5 & 20.6 & 16.0 & 22.3 & 26.9 & 20.4 & 23.9 & 22.9 & 21.2 & 25.3 & 21.9 \\
\hline Niger & 11.0 & 7.5 & 6.9 & 6.4 & 10.4 & 7.3 & 9.7 & 10.9 & 11.4 & 11.2 & 11.4 & 12.1 & 14.2 & 15.4 & 10.4 & 8.0 & 9.9 & 12.9 \\
\hline Senegal & 13.8 & 12.9 & 14.8 & 14.1 & 18.5 & 16.7 & 18.5 & 15.8 & 17.5 & 19.4 & 18.5 & 18.1 & 19.7 & 20.2 & 17.0 & 13.9 & 17.4 & 19.2 \\
\hline Togo & 25.0 & 14.3 & 13.4 & 6.3 & 13.0 & 12.6 & 13.5 & 11.8 & 16.4 & 13.3 & 14.8 & 15.2 & 13.2 & 14.5 & 14.1 & 14.8 & 13.5 & 14.2 \\
\hline WAEMU & 12.9 & 12.3 & 11.8 & 13.2 & 16.9 & 17.6 & 15.3 & 16.4 & 16.0 & 15.1 & 15.0 & 15.8 & 15.1 & 15.8 & 14.9 & 12.5 & 16.4 & 15.4 \\
\hline Average disparity & 6.0 & 5.3 & 5.9 & 5.2 & 5.5 & 5.7 & 4.0 & 3.9 & 3.5 & 2.7 & 4.4 & 5.2 & 4.2 & 5.0 & 4.3 & 5.2 & 4.2 & 4.1 \\
\hline
\end{tabular}

Table 4: WAEMU: Overall Fiscal Deficit (Commitment basis, in percent of GDP)

\begin{tabular}{|c|c|c|c|c|c|c|c|c|c|c|c|c|c|c|c|c|c|c|}
\hline & 1990 & 1991 & 1992 & 1993 & 1994 & 1995 & 1996 & 1997 & 1998 & 1999 & 2000 & 2001 & 2002 & 2003 & 1990-2003 & $1990-3$ & $1994-8$ & 1999-2003 \\
\hline Benin & -10.0 & -7.4 & -8.6 & -4.6 & -7.0 & -7.3 & -4.3 & -4.2 & -1.0 & -1.6 & -3.5 & -4.2 & -3.5 & -4.2 & -5.1 & -7.6 & -4.7 & -3.4 \\
\hline Burkina Faso & -6.4 & -7.3 & -8.1 & -9.0 & -9.6 & -8.3 & -7.9 & -8.9 & -8.1 & -11.0 & -10.7 & -11.1 & -10.2 & -9.2 & -9.0 & -7.7 & -8.6 & -10.4 \\
\hline Côte d'Ivoire & -19.3 & -13.7 & -12.8 & -13.6 & -0.8 & -4.4 & -2.7 & -2.7 & -2.8 & -3.3 & -1.7 & 0.4 & -1.7 & -2.5 & -5.8 & -14.9 & -2.7 & -1.8 \\
\hline Mali & -7.7 & -10.5 & -10.9 & -8.9 & -11.9 & -10.5 & -7.4 & -7.2 & -7.2 & -8.7 & -7.7 & -7.0 & -7.2 & -8.2 & -8.6 & -9.5 & -8.8 & -7.8 \\
\hline Niger & -12.4 & -8.4 & -8.6 & -9.4 & -12.5 & -8.0 & -5.3 & -7.5 & -8.2 & -9.9 & -8.1 & -7.9 & -7.7 & -8.1 & -8.7 & -9.7 & -8.3 & -8.4 \\
\hline Senegal & -1.8 & -0.6 & -3.8 & -4.2 & -6.1 & -3.5 & -4.4 & -2.0 & -3.3 & -3.5 & -2.0 & -3.9 & -1.6 & -4.4 & -3.2 & -2.6 & -3.9 & -3.1 \\
\hline Togo & -5.7 & -7.4 & -5.3 & -13.7 & -11.2 & -4.0 & -4.6 & -2.9 & -6.6 & -4.1 & -5.0 & -4.1 & -0.9 & -0.8 & -5.5 & -8.0 & -5.9 & -3.0 \\
\hline WAEMU & -11.2 & -8.8 & -9.2 & -9.8 & -5.7 & -5.7 & -4.4 & -4.1 & -4.3 & -5.0 & -4.1 & -3.6 & -3.8 & -4.8 & -6.0 & -9.7 & -4.9 & -4.3 \\
\hline Average disparity & 7.0 & 4.8 & 3.5 & 3.8 & 4.6 & 2.3 & 1.9 & 2.4 & 2.4 & 3.0 & 3.2 & 3.9 & 3.1 & 2.7 & 1.9 & 4.6 & 2.5 & 3.1 \\
\hline
\end{tabular}

Table 5: WAEMU: Primary Fiscal Balance (In percent of GDP)

\begin{tabular}{|c|c|c|c|c|c|c|c|c|c|c|c|c|c|c|c|c|c|c|}
\hline & 1990 & 1991 & 1992 & 1993 & 1994 & 1995 & 1996 & 1997 & 1998 & 1999 & 2000 & 2001 & 2002 & 2003 & $1990-2003$ & $1990-3$ & $1994-8$ & 1999-2003 \\
\hline $\begin{array}{l}\text { Benin } \\
\text { nat }\end{array}$ & -6.9 & -4.7 & -4.9 & $\begin{array}{c}-1.9 \\
\end{array}$ & -3.8 & -4.5 & -1.9 & -2.5 & 0.0 & -0.7 & -2.6 & -3.3 & -2.6 & -3.4 & -3.1 & -4.6 & -2.5 & -2.5 \\
\hline Burkina Faso & -5.4 & -6.0 & -6.8 & -7.6 & -8.4 & -7.1 & -7.1 & -8.2 & -7.4 & -10.3 & -9.8 & -10.3 & -9.4 & -8.5 & -8.0 & -6.5 & -7.6 & -9.7 \\
\hline Côte d'Ivoire & -9.5 & -2.8 & -2.4 & -5.4 & 6.4 & 1.9 & 2.5 & 1.7 & 1.0 & 0.5 & 2.4 & 3.7 & 1.3 & 0.4 & 0.1 & -5.0 & 2.7 & 1.6 \\
\hline Mali & -5.6 & -9.0 & -9.1 & -7.4 & -9.8 & -9.3 & -6.4 & -6.3 & -6.6 & -7.9 & -6.9 & -6.3 & -6.5 & -7.4 & -7.5 & -7.8 & -7.7 & -7.0 \\
\hline Niger & -10.1 & -6.5 & -6.9 & -7.7 & -10.2 & -5.7 & -3.7 & -6.0 & -6.6 & -8.3 & -6.5 & -6.1 & -6.3 & -7.0 & -7.0 & -7.8 & -6.4 & -6.8 \\
\hline Senegal & 0.8 & 1.7 & -1.8 & -1.9 & -2.6 & -0.6 & -2.0 & 0.3 & -2.0 & -2.1 & -0.5 & -3.0 & -0.5 & -3.2 & -1.2 & -0.3 & -1.4 & -1.8 \\
\hline Togo & -2.9 & -4.5 & -2.8 & -10.3 & -6.7 & -3.7 & -2.2 & -0.9 & -4.3 & -1.8 & -2.9 & -2.2 & 0.8 & 0.8 & -3.1 & -5.1 & -3.5 & -1.1 \\
\hline WAEMU & -6.1 & -3.4 & -4.0 & -5.3 & -1.2 & -2.0 & -1.2 & -1.3 & -2.0 & -2.7 & -1.7 & -1.7 & -2.0 & -3.1 & -2.7 & -4.7 & -1.5 & -2.2 \\
\hline Average disparity & 4.0 & 3.2 & 2.5 & 2.4 & 6.8 & 4.0 & 3.6 & 3.6 & 3.3 & 4.0 & 4.3 & 4.9 & 3.8 & 3.4 & 3.2 & 2.4 & 4.2 & 4.0 \\
\hline
\end{tabular}


Table 6: WAEMU: Tax Revenue (In percent of GDP)

\begin{tabular}{|c|c|c|c|c|c|c|c|c|c|c|c|c|c|c|c|c|c|c|}
\hline & 1990 & 1991 & 1992 & 1993 & 1994 & 1995 & 1996 & 1997 & 1998 & 1999 & 2000 & 2001 & 2002 & 2003 & $1990-2003$ & $1990-3$ & 1994-8 & 1999-2003 \\
\hline Benin & 7.9 & 8.9 & 10.1 & 11.2 & 11.0 & 12.3 & 12.5 & 12.6 & 13.3 & 13.7 & 14.6 & 14.2 & 15.0 & 15.1 & 12.3 & 9.5 & 12.3 & 14.5 \\
\hline Burkina Faso & 9.0 & 8.9 & 7.7 & 8.0 & 8.8 & 9.5 & 10.1 & 10.5 & 10.9 & 12.0 & 10.7 & 10.3 & 10.8 & 11.1 & 9.9 & 8.4 & 10.0 & 11.0 \\
\hline Côte d'Ivoire & 17.6 & 16.9 & 16.9 & 13.9 & 14.7 & 16.3 & 16.8 & 16.3 & 15.1 & 14.9 & 14.3 & 14.8 & 15.5 & 14.7 & 15.6 & 16.3 & 15.8 & 14.8 \\
\hline Mali & 9.8 & 10.2 & 10.3 & 10.3 & 8.7 & 9.4 & 11.8 & 12.2 & 12.5 & 12.5 & 12.3 & 12.7 & 13.8 & 14.2 & 11.5 & 10.1 & 10.9 & 13.1 \\
\hline Niger & 9.2 & 7.1 & 6.8 & 6.6 & 5.4 & 6.6 & 6.7 & 7.2 & 7.9 & 8.1 & 8.0 & 8.8 & 9.6 & 10.1 & 7.7 & 7.4 & 6.8 & 8.5 \\
\hline Senegal & 15.6 & 17.0 & 15.5 & 14.3 & 14.6 & 15.8 & 15.6 & 16.0 & 16.1 & 16.8 & 17.3 & 17.1 & 17.9 & 18.3 & 16.3 & 15.6 & 15.6 & 17 \\
\hline Togo & 17.5 & 14.2 & 11.5 & 7.8 & 9.8 & 11.5 & 11.6 & 11.7 & 12.3 & 11.9 & 11.2 & 11.1 & 11.2 & 13.2 & 11.9 & 12.8 & 11.4 & 11.7 \\
\hline WAEMU & 14.1 & 13.8 & 13.3 & 11.9 & 12.2 & 13.5 & 14.1 & 14.1 & 13.8 & 13.9 & 13.6 & 13.8 & 14.5 & 14.5 & 13.6 & 13.3 & 13.5 & 14.1 \\
\hline Average disparity & 3.9 & 3.9 & 3.8 & 2.8 & 3.2 & 3.4 & 3.1 & 2.8 & 2.3 & 2.2 & 2.5 & 2.4 & 2.5 & 2.3 & 2.8 & 3.5 & 2.9 & 2.3 \\
\hline
\end{tabular}

Table 7: WAEMU: Total Expenditure (In percent of GDP)

\begin{tabular}{|c|c|c|c|c|c|c|c|c|c|c|c|c|c|c|c|c|c|c|}
\hline & 1990 & 1991 & 1992 & 1993 & 1994 & 1995 & 1996 & 1997 & 1998 & 1999 & 2000 & 2001 & 2002 & 2003 & $1990-2003$ & $1990-3$ & 1994-8 & 1999-2003 \\
\hline Benin & 19.9 & 19.0 & 20.8 & 17.8 & 19.8 & 22.1 & 19.4 & 18.6 & 16.4 & 17.6 & 20.1 & 20.3 & 20.4 & 21.0 & 19.5 & 19.4 & 19.3 & $\overline{19.9}$ \\
\hline Burkina Faso & 17.4 & 19.1 & 18.5 & 19.9 & 19.2 & 18.5 & 18.8 & 20.4 & 19.9 & 23.9 & 22.3 & 22.2 & 21.8 & 21.6 & 20.2 & 18.7 & 19.4 & 22.3 \\
\hline Côte d'Ivoire & 40.7 & 33.2 & 33.0 & 30.1 & 19.1 & 24.5 & 22.5 & 22.1 & 21.2 & 19.8 & 18.1 & 16.6 & 19.3 & 19.0 & 24.2 & 34.3 & 21.9 & 18 \\
\hline Mali & 23.2 & 24.5 & 24.1 & 21.8 & 23.5 & 20.6 & 20.1 & 20.1 & 20.3 & 21.9 & 20.6 & 20.2 & 22.4 & 23.9 & 21.9 & 23.4 & 20.9 & 21 \\
\hline Niger & 22.7 & 16.9 & 16.8 & 16.8 & 18.6 & 15.2 & 13.1 & 16.0 & 17.3 & 18.7 & 16.7 & 17.2 & 18.4 & 18.7 & 17.4 & 18.3 & 16.0 & 18 \\
\hline Senegal & 20.0 & 20.0 & 22.2 & 20.8 & 21.0 & 19.9 & 21.0 & 19.0 & 20.1 & 20.9 & 20.0 & 21.7 & 20.5 & 23.6 & 20.8 & 20.8 & 20.2 & 21 \\
\hline Togo & 26.8 & 23.7 & 20.5 & 23.2 & 21.9 & 16.5 & 17.7 & 16.0 & 20.2 & 17.6 & 17.4 & 17.2 & 13.1 & 15.5 & 19.1 & 23.6 & 18.5 & 16. \\
\hline WAEMU & 28.6 & 25.2 & 25.4 & 24.0 & 20.1 & 21.4 & 20.4 & 20.2 & 20.1 & 20.2 & 19.2 & 18.9 & 19.8 & 20.7 & 21.7 & 25.8 & 20.4 & 19.7 \\
\hline Average disparity & 9.8 & 6.5 & 6.2 & 5.1 & 1.5 & 3.1 & 2.5 & 2.1 & 1.5 & 1.7 & 1.6 & 2.3 & 1.9 & 2.3 & 2.3 & 6.8 & 1.7 & 1. \\
\hline
\end{tabular}

Table 8: WAEMU: Current Expenditure (In percent of GDP)

\begin{tabular}{|c|c|c|c|c|c|c|c|c|c|c|c|c|c|c|c|c|c|c|}
\hline & 1990 & 1991 & 1992 & 1993 & 1994 & 1995 & 1996 & 1997 & 1998 & 1999 & 2000 & 2001 & 2002 & 2003 & 1990-2003 & 1990-3 & 1994-8 & 1999-2003 \\
\hline Benin & 11.0 & 10.8 & 11.5 & 10.3 & 10.1 & 11.5 & 10.7 & 10.1 & 9.5 & 10.3 & 11.6 & 11.7 & 13.1 & 13.1 & 11.1 & 10.9 & 10.4 & 12.0 \\
\hline Burkina Faso & 11.5 & 11.5 & 9.2 & 11.6 & 11.9 & 9.1 & 8.4 & 8.6 & 8.1 & 9.1 & 9.6 & 9.7 & 10.7 & 11.4 & 10.0 & 11.0 & 9.2 & 10.1 \\
\hline Côte d'Ivoire & 28.4 & 19.4 & 19.5 & 19.0 & 7.7 & 13.1 & 12.4 & 12.3 & 11.4 & 11.7 & 11.3 & 11.5 & 13.1 & 14.1 & 14.6 & 21.6 & 11.4 & 12 \\
\hline Mali & 14.1 & 18.7 & 13.7 & 12.0 & 10.7 & 8.4 & 8.0 & 9.5 & 8.7 & 10.0 & 9.6 & 11.5 & 12.6 & 12.6 & 11.4 & 14.6 & 9.1 & 11 \\
\hline Niger & 9.7 & 9.6 & 10.2 & 10.1 & 10.2 & 8.3 & 7.4 & 9.3 & 10.0 & 10.7 & 9.3 & 9.2 & 9.2 & 9.2 & 9.5 & 9.9 & 9.1 & 9.5 \\
\hline Senegal & 14.6 & 13.1 & 15.0 & 14.3 & 12.5 & 11.8 & 10.9 & 10.3 & 11.6 & 11.1 & 12.4 & 14.4 & 11.5 & 13.9 & 12.7 & 14.3 & 11.4 & 12 \\
\hline Togo & 17.2 & 16.5 & 14.7 & 17.7 & 15.4 & 13.2 & 12.8 & 12.1 & 14.0 & 12.2 & 12.3 & 13.0 & 10.0 & 12.8 & 13.9 & 16.6 & 13.5 & 12 \\
\hline WAEMU & 18.4 & 14.4 & 14.5 & 14.5 & 9.9 & 11.2 & 11.2 & 11.1 & 10.6 & 11.1 & 11.5 & 11.6 & 12.2 & 13.9 & 12.6 & 15.4 & 10.8 & 12 \\
\hline Average disparity & 7.6 & 3.9 & 3.9 & 3.6 & 2.3 & 1.9 & 1.9 & 1.4 & 1.5 & 0.9 & 1.1 & 1.5 & 1.3 & 1.6 & 1.9 & 4.6 & 1.2 & 1.0 \\
\hline
\end{tabular}

Table 9: WAEMU: Investment Expenditure (In percent of GDP)

\begin{tabular}{|c|c|c|c|c|c|c|c|c|c|c|c|c|c|c|c|c|c|c|}
\hline & 1990 & 1991 & 1992 & 1993 & 1994 & 1995 & 1996 & 1997 & 1998 & 1999 & 2000 & 2001 & 2002 & 2003 & 1990-2003 & $1990-3$ & 1994-8 & 1999-2003 \\
\hline Benin & 5.9 & 5.5 & 5.7 & 4.8 & 6.5 & 7.8 & 6.3 & 6.8 & 5.8 & 6.3 & 7.6 & 7.8 & 6.4 & 7.1 & 6.5 & 5.5 & 6.6 & 7.1 \\
\hline Burkina Faso & 4.8 & 6.3 & 8.0 & 7.0 & 6.1 & 8.2 & 9.6 & 11.0 & 11.2 & 14.0 & 11.8 & 11.7 & 10.3 & 9.5 & 9.3 & 6.5 & 9.2 & 11.5 \\
\hline Côte d'Ivoire & 2.5 & 2.9 & 3.0 & 2.9 & 4.2 & 5.1 & 4.9 & 5.4 & 6.0 & 4.2 & 2.8 & 1.8 & 3.2 & 2.0 & 3.7 & 2.9 & 5.1 & 2.8 \\
\hline Mali & 7.0 & 4.2 & 8.6 & 8.3 & 10.8 & 10.9 & 11.1 & 9.7 & 10.9 & 11.1 & 10.2 & 8.1 & 9.1 & 10.4 & 9.3 & 7.0 & 10.7 & 9.8 \\
\hline Niger & 10.7 & 5.3 & 4.9 & 4.9 & 6.0 & 4.6 & 4.1 & 5.1 & 5.7 & 6.5 & 5.7 & 6.2 & 7.7 & 8.4 & 6.1 & 6.4 & 5.1 & 6.9 \\
\hline Senegal & 2.9 & 4.6 & 5.2 & 4.2 & 5.0 & 5.3 & 7.7 & 6.4 & 7.2 & 8.3 & 6.2 & 6.4 & 7.9 & 8.5 & 6.1 & 4.2 & 6.3 & 7.4 \\
\hline Togo & 6.8 & 4.2 & 3.3 & 2.1 & 2.0 & 3.0 & 2.5 & 1.8 & 3.8 & 3.1 & 3.0 & 2.3 & 1.4 & 1.1 & 2.9 & 4.1 & 2.6 & 2.2 \\
\hline WAEMU & 5.1 & 5.5 & 5.7 & 5.0 & 5.6 & 6.4 & 6.0 & 6.3 & 7.1 & 6.8 & 5.2 & 5.3 & 5.9 & 5.1 & 5.8 & 5.3 & 6.3 & 5.7 \\
\hline Average disparity & 2.6 & 1.7 & 2.1 & 2.0 & 2.1 & 2.1 & 2.4 & 2.3 & 2.1 & 3.3 & 3.2 & 3.3 & 2.9 & 3.6 & 2.2 & 1.8 & 2.1 & 3.2 \\
\hline
\end{tabular}

Table 10: WAEMU: Civil Service Wage expenditures (as a share of current expenditure)

\begin{tabular}{|c|c|c|c|c|c|c|c|c|c|c|c|c|c|c|c|c|c|c|}
\hline & 1990 & 1991 & 1992 & 1993 & 1994 & 1995 & 1996 & 1997 & 1998 & 1999 & 2000 & 2001 & 2002 & 2003 & $1990-2003$ & 1990-3 & 1994-8 & 1999-2003 \\
\hline Benin & 65.6 & 65.0 & 59.7 & 61.1 & 54.4 & 46.6 & 48.0 & 48.6 & 49.3 & 43.6 & 40.2 & 39.8 & 36.5 & 38.7 & 49.8 & 62.9 & 49.4 & $\overline{39.8}$ \\
\hline Burkina Faso & 58.4 & 52.7 & 61.8 & 49.5 & 41.5 & 50.9 & 52.5 & 49.5 & 48.9 & 49.4 & 49.1 & 49.2 & 43.0 & 40.6 & 49.8 & 55.6 & 48.7 & 46.3 \\
\hline Côte d'Ivoire & 42.4 & 59.3 & 58.0 & 56.1 & 88.7 & 48.1 & 50.5 & 48.7 & 48.4 & 47.1 & 52.7 & 53.6 & 49.0 & 48.9 & 53.7 & 54.0 & 56.9 & 50.2 \\
\hline Mali & 36.2 & 28.9 & 39.7 & 41.9 & 34.9 & 40.8 & 43.2 & 37.1 & 39.3 & 36.5 & 40.0 & 32.2 & 30.4 & 31.9 & 36.6 & 36.7 & 39.0 & 34. \\
\hline Niger & 55.8 & 61.2 & 61.2 & 63.2 & 53.3 & 63.5 & 44.4 & 43.9 & 36.7 & 38.1 & 43.5 & 38.4 & 39.8 & 39.1 & 48.7 & 60.4 & 48.3 & 39 \\
\hline Senegal & 55.9 & 63.6 & 57.8 & 60.1 & 58.8 & 60.0 & 62.0 & 59.5 & 50.1 & 51.2 & 45.7 & 36.5 & 49.2 & 39.6 & 53.6 & 59.4 & 58.1 & 44 \\
\hline Togo & 45.1 & 52.4 & 54.8 & 54.9 & 52.3 & 51.5 & 49.5 & 47.5 & 44.7 & 49.6 & 48.1 & 43.7 & 50.4 & 38.1 & 48.7 & 51.8 & 49.1 & 46 \\
\hline WAEMU & 49.1 & 56.5 & 56.8 & 55.5 & 65.6 & 50.8 & 51.2 & 48.9 & 46.8 & 46.2 & 47.9 & 45.0 & 44.5 & 42.1 & 50.5 & 54.5 & 52.7 & 45 \\
\hline Average disparity & 8.6 & 9.9 & 5.9 & 5.8 & 20.4 & 6.4 & 5.5 & 5.8 & 4.1 & 4.5 & 4.9 & 8.2 & 6.6 & 5.8 & 5.2 & 6.7 & 6.0 & 5. \\
\hline
\end{tabular}


Table 11: WAEMU: Civil Service Wage Expenditures (In percent of GDP)

\begin{tabular}{|c|c|c|c|c|c|c|c|c|c|c|c|c|c|c|c|c|c|c|}
\hline & 1990 & 1991 & 1992 & 1993 & 1994 & 1995 & 1996 & 1997 & 1998 & 1999 & 2000 & 2001 & 2002 & 2003 & $1990-2003$ & $1990-3$ & $1994-8$ & 1999-2003 \\
\hline Benin & 7.2 & 7.0 & 6.9 & 6.3 & 5.5 & 5.4 & 5.1 & 4.9 & 4.7 & 4.5 & 4.7 & 4.6 & 4.8 & 5.1 & 5.5 & 6.9 & 5.1 & 4.7 \\
\hline Burkina Faso & 6.7 & 6.1 & 5.7 & 5.7 & 4.9 & 4.6 & 4.4 & 4.3 & 3.9 & 4.5 & 4.7 & 4.8 & 4.6 & 4.6 & 5.0 & 6.1 & 4.4 & 4.6 \\
\hline Côte d'Ivoire & 12.0 & 11.5 & 11.3 & 10.7 & 6.8 & 6.3 & 6.3 & 6.0 & 5.5 & 5.5 & 5.9 & 6.2 & 6.4 & 6.9 & 7.7 & 11.4 & 6.2 & 6.2 \\
\hline Mali & 5.1 & 5.4 & 5.5 & 5.0 & 3.7 & 3.4 & 3.5 & 3.5 & 3.4 & 3.6 & 3.8 & 3.7 & 3.8 & 4.0 & 4.1 & 5.2 & 3.5 & 3. \\
\hline Niger & 5.4 & 5.9 & 6.3 & 6.4 & 5.5 & 5.3 & 3.3 & 4.1 & 3.7 & 4.1 & 4.0 & 3.5 & 3.7 & 3.6 & 4.6 & 6.0 & 4.4 & 3.8 \\
\hline Senegal & 8.2 & 8.3 & 8.7 & 8.6 & 7.4 & 7.1 & 6.8 & 6.1 & 5.8 & 5.7 & 5.6 & 5.2 & 5.7 & 5.5 & 6.8 & 8.5 & 6.6 & 5. \\
\hline Togo & 7.8 & 8.7 & 8.1 & 9.7 & 8.0 & 6.8 & 6.3 & 5.8 & 6.3 & 6.1 & 5.9 & 5.7 & 5.0 & 4.9 & 6.8 & 8.6 & 6.6 & 5.5 \\
\hline WAEMU & 8.9 & 8.7 & 8.7 & 8.4 & 6.3 & 5.8 & 5.6 & 5.4 & 5.0 & 5.1 & 5.3 & 5.2 & 5.4 & 5.5 & 6.4 & 8.7 & 5.6 & 5.3 \\
\hline Average disparity & 2.7 & 2.4 & 2.3 & 2.2 & 1.2 & 1.1 & 1.2 & 0.9 & 0.9 & 0.7 & 0.8 & 0.9 & 1.0 & 1.2 & 1.3 & 2.4 & 1.0 & 0. \\
\hline
\end{tabular}

Table 12: WAEMU: External Trade (Goods and Services) to GDP

\begin{tabular}{|c|c|c|c|c|c|c|c|c|c|c|c|c|c|c|c|c|c|c|}
\hline & 1990 & 1991 & 1992 & 1993 & 1994 & 1995 & 1996 & 1997 & 1998 & 1999 & 2000 & 2001 & 2002 & 2003 & 1990-2003 & 1990-3 & 1994-8 & 1999-2003 \\
\hline Benin & 37.0 & 39.3 & 39.1 & 37.7 & $\begin{array}{ll}46.8 \\
\end{array}$ & 50.0 & 47.6 & 45.0 & 44.6 & 44.9 & 42.9 & 42.4 & 40.5 & 40.0 & 42.7 & 38.3 & 46.8 & $\overline{42.1}$ \\
\hline Burkina Faso & 35.6 & 34.3 & 30.4 & 33.1 & 33.9 & 36.5 & 34.7 & 34.1 & 37.5 & 34.1 & 33.7 & 32.4 & 30.0 & 30.9 & 33.6 & 33.3 & 35.3 & 32.2 \\
\hline Côte d'Ivoire & 58.8 & 57.0 & 63.2 & 55.3 & 69.8 & 76.2 & 73.5 & 74.5 & 72.5 & 72.4 & 72.3 & 73.4 & 79.4 & 79.3 & 69.8 & 58.6 & 73.3 & \\
\hline Mali & 43.5 & 44.6 & 45.5 & 43.4 & 54.2 & 56.2 & 51.2 & 56.0 & 52.1 & 57.2 & 58.9 & 67.5 & 67.4 & 59.8 & 54.1 & 44.3 & 54.0 & 62.1 \\
\hline Niger & 36.4 & 32.8 & 34.6 & 33.7 & 43.4 & 42.0 & 44.4 & 41.5 & 44.1 & 39.1 & 43.4 & 41.5 & 43.1 & 44.4 & 40.3 & 34.4 & 43.1 & 42 \\
\hline Senegal & 58.9 & 56.3 & 54.0 & 52.9 & 76.5 & 74.6 & 65.3 & 65.0 & 67.0 & 68.7 & 69.5 & 70.3 & 70.6 & 68.2 & 65.6 & 55.5 & 69.7 & 69 \\
\hline Togo & 74.3 & 70.0 & 59.1 & 49.9 & 59.3 & 62.4 & 68.6 & 65.5 & 73.0 & 67.8 & 76.6 & 77.9 & 82.9 & 93.7 & 70.1 & 63.3 & 65.8 & 79. \\
\hline WAEMU & 53.0 & 51.0 & 52.9 & 47.8 & 56.9 & 61.3 & 68.6 & 68.0 & 60.5 & 66.0 & 66.3 & 63.4 & 65.7 & 73.2 & 61.0 & 51.2 & 63.1 & 66.9 \\
\hline
\end{tabular}

Table 13: WAEMU: Share of the Two Main Commodities in Total Exports

\begin{tabular}{|c|c|c|c|c|c|c|c|c|c|c|c|c|c|c|c|c|c|c|}
\hline & 1990 & 1991 & 1992 & 1993 & 1994 & 1995 & 1996 & 1997 & 1998 & 1999 & 2000 & 2001 & 2002 & 2003 & 1990-2003 & $1990-3$ & 1994-8 & 1999-2003 \\
\hline Benin & 89.7 & 92.8 & 91.1 & 88.1 & 83.8 & 81.0 & 87.3 & 84.3 & 85.4 & 83.5 & 80.4 & 75.1 & 67.2 & 68.6 & 82.7 & 90.4 & 84.4 & $\overline{74.9}$ \\
\hline Burkina Faso & 47.7 & 49.4 & 53.6 & 40.8 & 62.1 & 73.3 & 69.4 & 76.1 & 77.7 & 72.3 & 71.3 & 77.5 & 80.3 & 75.9 & 66.2 & 47.9 & 71.7 & \\
\hline Côte d'Ivoire & 37.0 & 41.6 & 39.6 & 47.2 & 41.8 & 43.6 & 43.8 & 42.9 & 46.2 & 39.9 & 35.9 & 38.4 & 46.5 & 44.9 & 42.1 & 41.3 & 43.7 & 41 \\
\hline Mali & 76.0 & 75.2 & 67.5 & 65.2 & 73.6 & 75.6 & 74.5 & 58.7 & 53.3 & 52.3 & 40.3 & 24.1 & 29.7 & 34.7 & 57.2 & 71.0 & 67.1 & 36 \\
\hline Niger & 85.7 & 88.8 & 86.7 & 84.5 & 86.3 & 66.4 & 54.3 & 61.1 & 51.0 & 51.9 & 50.2 & 51.7 & 52.0 & 48.7 & 65.7 & 86.4 & 63.8 & 50 \\
\hline Senegal & 45.4 & 45.4 & 40.8 & 41.6 & 43.8 & 43.5 & 44.3 & 47.0 & 43.6 & 40.4 & 33.5 & 35.6 & 39.7 & 34.9 & 41.4 & 43.3 & 44.4 & 36 \\
\hline Togo & 40.2 & 48.7 & 41.4 & 46.2 & 52.1 & 55.0 & 48.9 & 46.4 & 44.1 & 37.6 & 25.0 & 18.5 & 23.4 & 20.7 & 39.2 & 44.1 & 49.3 & 25.1 \\
\hline WAEMU & 48.1 & 52.0 & 47.9 & 51.9 & 51.3 & 51.9 & 50.3 & 48.8 & 50.1 & 44.8 & 39.9 & 39.9 & 45.2 & 43.5 & 47.5 & 50.0 & 50.5 & 42 \\
\hline
\end{tabular}

Table 14: WAEMU: Ratio of Intrazone Exports to Total Exports

\begin{tabular}{|c|c|c|c|c|c|c|c|c|c|c|c|c|c|c|c|c|c|c|}
\hline & 1990 & 1991 & 1992 & 1993 & 1994 & 1995 & 1996 & 1997 & 1998 & 1999 & 2000 & 2001 & 2002 & 2003 & 1990-2003 & 1990-3 & 1994-8 & 1999-2003 \\
\hline Benin & 5.0 & 1.3 & 2.2 & 1.5 & 2.0 & 1.3 & 1.8 & 2.5 & 2.1 & 2.6 & 3.2 & 3.2 & 3.3 & 6.0 & 2.7 & 2.5 & 1.9 & 3.7 \\
\hline Burkina Faso & 6.9 & 4.9 & 6.8 & 7.9 & 10.6 & 13.8 & 12.1 & 10.7 & 1.8 & 1.7 & 3.7 & 4.6 & 4.5 & 5.3 & 6.8 & 6.6 & 9.8 & 4.0 \\
\hline Côte d'Ivoire & 12.7 & 12.9 & 11.5 & 9.5 & 9.2 & 8.6 & 9.7 & 11.0 & 11.5 & 12.5 & 14.1 & 12.7 & 10.0 & 8.6 & 11.0 & 11.7 & 10.0 & 11.6 \\
\hline Mali & 3.6 & 1.1 & 2.7 & 2.6 & 0.9 & 0.9 & 1.2 & 0.7 & 1.0 & 0.5 & 1.0 & 0.5 & 0.4 & 0.3 & 1.2 & 2.5 & 0.9 & 0.5 \\
\hline Niger & 3.3 & 2.8 & 2.6 & 2.1 & 5.5 & 3.4 & 5.0 & 3.9 & 4.5 & 4.1 & 3.6 & 2.4 & 3.0 & 1.4 & 3.4 & 2.7 & 4.5 & 2.9 \\
\hline Senegal & 6.1 & 2.4 & 3.8 & 4.6 & 4.5 & 5.3 & 6.7 & 7.3 & 7.1 & 7.1 & 5.7 & 6.9 & 10.2 & 13.5 & 6.5 & 4.2 & 6.2 & 8.7 \\
\hline Togo & 3.6 & 2.9 & 4.5 & 3.2 & 2.4 & 2.9 & 3.4 & 4.0 & 4.6 & 5.1 & 5.8 & 17.9 & 16.5 & 21.7 & 7.0 & 3.6 & 3.4 & 13.4 \\
\hline WAEMU & 8.9 & 7.6 & 7.8 & 6.9 & 6.9 & 6.8 & 7.8 & 8.6 & 8.5 & 9.2 & 9.8 & 9.5 & 8.6 & 8.9 & 8.3 & 7.8 & 7.7 & 9.2 \\
\hline
\end{tabular}

Table 15: WAEMU: Weight of Each Country in Intrazone Exports of Goods

\begin{tabular}{|c|c|c|c|c|c|c|c|c|c|c|c|c|c|c|c|c|c|c|}
\hline & 1990 & 1991 & 1992 & 1993 & 1994 & 1995 & 1996 & 1997 & 1998 & 1999 & 2000 & 2001 & 2002 & 2003 & $1990-2003$ & $1990-3$ & 1994-8 & 1999-2003 \\
\hline $\begin{array}{l}\text { Benin } \\
\end{array}$ & 2.0 & 0.7 & 1.2 & 1.0 & 1.4 & 0.9 & 1.1 & 1.2 & 1.1 & 1.3 & 1.5 & 1.5 & 1.5 & 2.9 & 1.4 & 1.2 & 1.2 & 1.7 \\
\hline Burkina Faso & 4.0 & 3.4 & 3.7 & 6.1 & 6.1 & 7.6 & 5.1 & 4.1 & 0.9 & 0.6 & 1.2 & 1.6 & 1.5 & 2.0 & 3.4 & 4.3 & 4.8 & 1.2 \\
\hline Côte d'Ivoire & 71.2 & 83.1 & 77.6 & 73.2 & 73.1 & 71.6 & 73.5 & 76.4 & 78.5 & 80.0 & 81.5 & 72.9 & 66.9 & 54.1 & 73.8 & 76.3 & 74.6 & 71. \\
\hline Mali & 2.5 & 1.0 & 2.1 & 2.7 & 0.8 & 0.8 & 1.0 & 0.7 & 0.8 & 0.4 & 0.9 & 0.6 & 0.6 & 0.3 & 1.1 & 2.1 & 0.8 & 0. \\
\hline Niger & 2.0 & 1.9 & 1.9 & 1.8 & 3.3 & 2.0 & 2.8 & 1.7 & 2.2 & 1.7 & 1.6 & 1.0 & 1.3 & 0.6 & 1.8 & 1.9 & 2.4 & 1. \\
\hline Senegal & 15.0 & 6.7 & 9.7 & 13.0 & 13.6 & 14.6 & 14.0 & 13.4 & 13.6 & 13.1 & 10.2 & 12.7 & 18.5 & 24.3 & 13.7 & 11.1 & 13.8 & 15. \\
\hline Togo & 3.3 & 3.2 & 3.7 & 2.3 & 1.7 & 2.4 & 2.5 & 2.5 & 2.9 & 2.9 & 3.2 & 9.6 & 9.8 & 15.7 & 4.7 & 3.1 & 2.4 & 8. \\
\hline WAEMU & 100.0 & 100.0 & 100.0 & 100.0 & 100.0 & 100.0 & 100.0 & 100.0 & 100.0 & 100.0 & 100.0 & 100.0 & 100.0 & 100.0 & 100.0 & 100.0 & 100.0 & 100. \\
\hline
\end{tabular}

Table 16: WAEMU: Ratio of Intrazone Imports to Total Imports

\begin{tabular}{|c|c|c|c|c|c|c|c|c|c|c|c|c|c|c|c|c|c|c|}
\hline & 1990 & 1991 & 1992 & 1993 & 1994 & 1995 & 1996 & 1997 & 1998 & 1999 & 2000 & 2001 & 2002 & 2003 & $1990-2003$ & $1990-3$ & 1994-8 & 1999-2003 \\
\hline Benin & 6.7 & 1.2 & 3.5 & 3.1 & 4.4 & 6.7 & 7.1 & 6.9 & 7.8 & 23.1 & 11.3 & 13.2 & 13.5 & 17.9 & 9.0 & 3.6 & 6.6 & 15.8 \\
\hline Burkina Faso & 15.8 & 16.9 & 15.2 & 12.2 & 14.8 & 13.1 & 15.3 & 15.7 & 22.8 & 29.2 & 22.3 & 25.6 & 29.8 & 25.9 & 19.6 & 15.0 & 16.3 & 26.5 \\
\hline Côte d'Ivoire & 1.1 & 1.3 & 0.8 & 0.8 & 0.6 & 0.6 & 0.7 & 0.6 & 0.7 & 0.6 & 0.5 & 0.7 & 0.8 & 1.0 & 0.8 & 1.0 & 0.6 & 0.7 \\
\hline Mali & 26.1 & 22.8 & 20.7 & 19.3 & 21.9 & 20.7 & 27.5 & 29.8 & 31.2 & 28.0 & 30.0 & 24.9 & 26.3 & 18.7 & 24.9 & 22.2 & 26.2 & 25 \\
\hline Niger & 8.4 & 8.4 & 9.5 & 9.1 & 7.1 & 7.9 & 7.4 & 9.7 & 10.6 & 13.9 & 13.8 & 15.0 & 15.1 & 14.7 & 10.8 & 8.8 & 8.5 & 14 \\
\hline Senegal & 4.1 & 3.6 & 4.6 & 3.1 & 2.3 & 1.8 & 2.3 & 2.1 & 2.3 & 2.8 & 2.4 & 2.9 & 2.8 & 3.6 & 2.9 & 3.8 & 2.1 & \\
\hline Togo & 8.3 & 3.7 & 6.8 & 6.2 & 9.9 & 5.4 & 4.9 & 5.0 & 5.7 & 5.1 & 7.0 & 4.9 & 5.1 & 5.8 & 6.0 & 6.2 & 6.2 & 5.6 \\
\hline WAEMU & 7.1 & 6.2 & 6.0 & 5.4 & 5.8 & 5.2 & 6.1 & 6.2 & 7.2 & 8.8 & 7.8 & 8.1 & 8.4 & 8.1 & 6.9 & 6.1 & 6.1 & 8. \\
\hline
\end{tabular}


Table 17: WAEMU: Weight of Each Country in Intrazone Imports of Goods

\begin{tabular}{|c|c|c|c|c|c|c|c|c|c|c|c|c|c|c|c|c|c|c|}
\hline & 1990 & 1991 & 1992 & 1993 & 1994 & 1995 & 1996 & 1997 & 1998 & 1999 & 2000 & 2001 & 2002 & 2003 & $1990-2003$ & 1990-3 & 1994-8 & 1999-2003 \\
\hline Benin & 5.1 & 1.2 & 3.8 & 4.1 & 4.9 & 8.8 & 8.2 & 7.8 & 7.3 & 19.5 & 10.8 & 11.9 & 12.0 & 16.8 & 8.7 & 3.5 & 7.4 & $\overline{14.2}$ \\
\hline Burkina Faso & 21.2 & 26.5 & 22.0 & 22.8 & 19.5 & 18.7 & 20.3 & 18.9 & 26.5 & 26.0 & 22.0 & 23.0 & 25.4 & 24.2 & 22.7 & 23.1 & 20.8 & \\
\hline Côte d'Ivoire & 5.8 & 7.8 & 5.2 & 5.8 & 4.0 & 4.6 & 4.9 & 4.0 & 4.5 & 2.8 & 2.8 & 3.5 & 3.7 & 4.8 & 4.6 & 6.1 & 4.4 & \\
\hline Mali & 35.9 & 38.4 & 35.9 & 39.0 & 44.8 & 47.0 & 47.0 & 49.1 & 41.7 & 33.6 & 41.9 & 40.0 & 36.6 & 27.4 & 39.9 & 37.3 & 45.9 & 35 \\
\hline Niger & 7.9 & 7.7 & 7.9 & 9.3 & 8.0 & 7.9 & 7.0 & 8.0 & 8.5 & 8.0 & 9.6 & 9.9 & 10.8 & 11.4 & 8.7 & 8.2 & 7.9 & \\
\hline Senegal & 13.4 & 13.2 & 16.9 & 12.9 & 9.2 & 7.0 & 6.8 & 5.9 & 5.9 & 6.2 & 6.3 & 7.4 & 7.0 & 9.5 & 9.1 & 14.1 & 7.0 & \\
\hline Togo & 10.8 & 5.2 & 8.4 & 6.2 & 9.6 & 5.9 & 5.8 & 6.2 & 5.7 & 3.9 & 6.6 & 4.3 & 4.6 & 5.9 & 6.4 & 7.6 & 6.6 & \\
\hline WAEMU & 100.0 & 100.0 & 100.0 & 100.0 & 100.0 & 100.0 & 100.0 & 100.0 & 100.0 & 100.0 & 100.0 & 100.0 & 100.0 & 100.0 & 100.0 & 100.0 & 100.0 & 100. \\
\hline
\end{tabular}

Table 18: WAEMU: Growth of Intrazone Exports

\begin{tabular}{|c|c|c|c|c|c|c|c|c|c|c|c|c|c|c|c|c|c|c|}
\hline & 1990 & 1991 & 1992 & 1993 & 1994 & 1995 & 1996 & 1997 & 1998 & 1999 & 2000 & 2001 & 2002 & 2003 & $1990-2003$ & $1990-3$ & 1994-8 & 1999-2003 \\
\hline Benin & & -71.9 & 89.2 & -38.4 & 42.2 & -10.6 & 45.7 & 14.7 & -1.8 & 19.9 & 7.1 & 5.1 & 7.6 & 139.8 & 19.1 & -7.1 & 18.0 & $\overline{35.9}$ \\
\hline Burkina Faso & & -31.9 & 24.7 & 25.0 & 0.5 & 63.1 & -20.8 & -14.5 & -77.9 & -24.6 & 82.5 & 37.3 & 2.7 & 67.4 & 10.3 & 6.0 & -9.9 & 33 \\
\hline Côte d'Ivoire & & -6.2 & 5.0 & -27.5 & 0.3 & 27.6 & 22.0 & 10.2 & 9.1 & 9.1 & -6.5 & -6.6 & 0.9 & -1.4 & 2.8 & -9.6 & 13.8 & -0.9 \\
\hline Mali & & -66.8 & 135.7 & -2.9 & -68.5 & 25.5 & 42.8 & -25.8 & 31.0 & -46.7 & 88.4 & -23.5 & -3.7 & -26.9 & 4.5 & 22.0 & 1.0 & -2 \\
\hline Niger & & -25.1 & 13.0 & -28.7 & 90.7 & -21.4 & 65.0 & -33.6 & 35.1 & -20.3 & -12.2 & -31.2 & 36.5 & -40.3 & 2.1 & -13.6 & 27.2 & -13.5 \\
\hline Senegal & & -64.2 & 62.1 & 3.2 & 4.7 & 40.8 & 13.4 & 1.5 & 7.7 & 3.4 & -28.4 & 30.2 & 59.5 & 60.0 & 14.9 & 0.4 & 13.6 & 24 \\
\hline Togo & & -20.9 & 30.3 & -52.6 & -26.4 & 86.9 & 23.0 & 4.9 & 26.1 & 7.1 & 0.1 & 213.1 & 13.2 & 94.8 & 30.7 & -14.4 & 22.9 & 65 \\
\hline WAEMU & & -19.7 & 12.4 & -23.1 & 0.4 & 30.4 & 18.8 & 6.1 & 6.2 & 7.0 & -8.2 & 4.3 & 10.0 & 21.9 & 5.1 & -10.1 & 12.4 & 7. \\
\hline
\end{tabular}

Table 19: WAEMU: Growth of Intrazone Imports

\begin{tabular}{|c|c|c|c|c|c|c|c|c|c|c|c|c|c|c|c|c|c|c|}
\hline & 1990 & 1991 & 1992 & 1993 & 1994 & 1995 & 1996 & 1997 & 1998 & 1999 & 2000 & 2001 & 2002 & 2003 & $1990-2003$ & $1990-3$ & 1994-8 & 1999-2003 \\
\hline Benin & & -81.1 & 244.9 & -15.2 & 12.4 & 127.2 & 9.9 & -5.1 & 17.1 & 217.3 & -54.9 & 20.5 & 13.1 & 66.7 & 44.1 & 49.5 & 32.3 & $\overline{52.5}$ \\
\hline Burkina Faso & & 5.2 & -12.6 & -18.1 & -19.8 & 20.4 & 27.9 & -7.0 & 75.8 & 16.8 & -30.9 & 13.2 & 24.2 & 13.9 & 8.4 & -8.5 & 19.5 & \\
\hline Côte d'Ivoire & & 12.7 & -29.3 & -11.3 & -36.4 & 45.7 & 25.3 & -17.4 & 38.6 & -24.9 & -18.4 & 34.6 & 18.2 & 55.0 & 7.1 & -9.3 & 11.2 & 12. \\
\hline Mali & & -10.2 & -1.3 & -14.1 & 7.5 & 31.5 & 18.1 & 4.1 & 6.5 & -4.0 & 1.9 & 3.4 & 3.0 & -10.7 & 2.7 & -8.6 & 13.5 & -1 \\
\hline Niger & & -18.2 & 8.0 & -7.7 & -18.6 & 22.7 & 4.3 & 15.1 & 32.1 & 12.6 & -2.5 & 12.6 & 22.4 & 26.4 & 8.4 & -6.0 & 11.1 & 14 \\
\hline Senegal & & -17.1 & 35.0 & -39.6 & -32.9 & -5.3 & 15.4 & -14.0 & 24.5 & 26.7 & -17.0 & 27.5 & 5.6 & 62.4 & 5.5 & -7.2 & -2.4 & 21 \\
\hline Togo & & -59.7 & 70.4 & -41.9 & 45.5 & -22.4 & 16.3 & 5.6 & 16.6 & -20.2 & 39.1 & -29.3 & 20.4 & 54.2 & 7.3 & -10.4 & 12.3 & 12 \\
\hline WAEMU & & -16.1 & 5.6 & -21.0 & -6.4 & 25.3 & 18.2 & -0.4 & 25.5 & 19.0 & -18.4 & 8.6 & 12.5 & 19.3 & 5.5 & -10.5 & 12.5 & 8. \\
\hline
\end{tabular}




\section{REFERENCES}

Bayoumi, T., and J. D. Ostry, 1995, "Macroeconomic Shocks and Trade Flows Within SubSaharan Africa: Implications for Optimum Currency Arrangements,” IMF Working Paper No. 95/142 (Washington, DC: International Monetary Fund).

Clément, J., J. Mueller, S. Cossé, and J. LeDem, 1996, “Aftermath of the CFA Franc Devaluation,” IMF Occasional Paper No. 138 (Washington, DC: International Monetary Fund).

Commission of the European Union, 1997, Programme d'Appui Régional à l'Intégration des Pays de l'UEMOA (Brussels: The Commission).

Devarajan, S., G. D. Lewis, and S. Robinson, 1993, "External Shocks, Purchasing Power Parity, and the Equilibrium Real Exchange Rate, World Bank Economic Review 7 (1): 45-63.

Doré, O., B. Anne, and D. Engmann, 2003, "Regional Impact of Côte d'Ivoire's Sociopolitical Crisis: An Assessment,” IMF Working Paper No. 03/85 (Washington, DC: International Monetary Fund).

Doré, O. and P. R. Masson, 2002, "Experience with Budgetary Convergence in the WAEMU,” IMF Working Paper 02/108 (Washington, DC: International Monetary Fund).

Faroutan, F., and L. Prichett, 1993, "Intra-sub-Saharan African Trade: Is There Too Little?” Journal of African Economies, Vol. 2, pp. 74-105.

Hadjimichael, M.T., and M. Galy, 1997, “The CFA Franc Zone and the EMU,” IMF Working Paper No. 97/156 (Washington, DC: International Monetary Fund).

Halevy, N., and E. Kleiman, 1995, "Regional Versus Non-Regional Integration: the Case of the Middle East” (mimeo, Jerusalem: Hebrew University).

Hernández-Catá, E., C. A. François, P. Masson, P. Bouvier, P. Peroz, D. Desruelle, and A. Vamvakidis, 1998, “The West African Economic and Monetary Union,Recent Developments and Policy Issues,” IMF Occasional Paper No. 170 (Washington: International Monetary Fund).

Hinkle, L., and P. J. Montiel, 1999, Exchange Rate Misalignment: Concepts and Measurement for Developing Countries (Washington: World Bank).

Hinkle, L. and F. Nsengiyumva, 1997, "Internal Real Exchange Rates: Concepts and Measurement”, in Exchange Rate Misalignment: Concepts and Measurement for Developing Countries edited by L. Hinkle and P. Montiel (Washington: World Bank). 
“IMF-AERC Seminar on Africa, Trade Liberalization, Regional Initiatives Explored,” 1997, IMF Survey December 15, 1997, pp. 392-394.

Kenen, P. B., 1969, “The Theory of Optimum Currency Areas: An Eclectic View,” in Monetary Problems of the International Economy, edited by Mundell and Swoboda (Chicago and London: University of Chicago Press).

Kose M. A., and R. Riezman, 2001, “Trade Shocks and Macroeconomic Fluctuations in Africa,” Journal of Development Economics, 65, pp. 55-80.

Masson, P. R. and C. Pattillo, 2004, The Monetary Geography of Africa, (Washington, D.C.: Brookings Institution). , 2001, “Monetary Union in West Africa: An Agency of Restraint for Fiscal Policies?” IMF Working Paper 01/34 (Washington, DC: International Monetary Fund). , 2001, “Monetary Union in West Africa (ECOWAS),” IMF Occasional Paper

(Washington, DC: International Monetary Fund).

Nashashibi, K. and S. Bazzoni, 1994, "Exchange Rate Strategies and Fiscal Performance in Sub-Saharan Africa,” IMF Staff Papers, International Monetary Fund, Vol. 41, pp. 76-122.

Rogoff, K., and C. Reinhart, 2003, "FDI to Africa: The Role of Price Stability and Currency Instability,” IMF Working Paper 03/10 (Washington, DC: International Monetary Fund).

Rosenberg, C., 1995, “Fiscal Policy Coordination in the WAEMU After the Devaluation,” IMF Working Paper No. 95/25 (Washington, DC: International Monetary Fund).

Rother, P. C., 1998, "Money Demand and Regional Monetary Policy in the West African Economic and Monetary Union,” IMF Working Paper 98/57 (Washington, DC: International Monetary Fund).

Snerch, S., 1994, “Pour Préparer l'Avenir de l’Afrique de l’Ouest: une Vision à l'Horizon 2020," Etude des Perspectives à Long Terme en Afrique de l’Ouest,” SAH/94/439, OECD/ADB/CILSS.

Wane, A., 2004, “Growth and Convergence in WAEMU Countries,” IMF Working Paper 04/198 (Washington, DC: International Monetary Fund). 